\title{
SYNTHESIS AND ION SENSING PROPERTIES OF NEW COLORIMETRIC AND FLUORIMETRIC CHEMOSENSORS BASED ON BITHIENYL-IMIDAZO-ANTHRAQUINONE CHROMOPHORES
}

\author{
Rosa M. F. Batista ${ }^{\S}$, Elisabete Oliveira ${ }^{\ddagger}$ Susana P. G. Costa ${ }^{\S}$, Carlos Lodeiro ${ }^{\ddagger}$, M. Manuela M. \\ $\operatorname{Raposo}^{\S *}$ \\ ${ }^{\S}$ Centro de Química, Universidade do Minho, Campus de Gualtar, 4710-057 Braga, Portugal \\ ${ }^{*}$ REQUIMTE, Faculdade de Ciências e Tecnologia, Universidade Nova de Lisboa, 2829-516 Monte de \\ Caparica, Portugal. \\ mfox@quimica.uminho.pt,lodeiro@dq.fct.unl.pt
}

\section{Supporting Information}

\section{Contents}

1. Experimental Section $\quad$ S2

$\begin{array}{ll}\text { 1.1. Synthesis general } & \mathrm{S} 2\end{array}$

1.2. Procedure for the synthesis of aldehyde 1c through Suzuki cross-coupling

1.3. General procedure for the synthesis of compounds $\mathbf{2 a - c} \quad$ S3

2. ${ }^{1} \mathrm{H}$ and ${ }^{13} \mathrm{C}$ NMR spectra of compounds 1c and 2a-c S6

3. Spectrophotometric and spectrofluorimetric studies of compounds 2a-c S13

$\begin{array}{ll}\text { 3.1. General } & \text { S13 }\end{array}$

3.2. Proton sensing ability of compounds 2a-c $\quad \mathrm{S} 13$

3.3. Basic anions $\left(\mathrm{CN}^{-}, \mathrm{CH}_{3} \mathrm{COO}^{-}\right.$and $\left.\mathrm{H}_{2} \mathrm{PO}_{4}^{-}\right)$sensing ability of

compound 2a S15

3.4. Halide ion ( $\mathrm{Br}^{-}, \mathrm{Cl}^{-}$and $\left.\mathrm{I}^{-}\right)$sensing ability of compounds 2a-c $\quad \mathrm{S} 15$

$\begin{array}{ll}\text { 3.5. Fluoride ion sensing ability of compounds 2a-c } & \text { S17 }\end{array}$

3.6. UV-vis and emission titration of $\mathbf{2 a - c}$ with metal ions

( $\mathrm{Zn}(\mathrm{II}), \mathrm{Cu}(\mathrm{II})$ and $\mathrm{Hg}(\mathrm{II})$ ), after fluoride ion addition $\mathrm{S} 21$

4. References 


\section{Experimental Section}

\subsection{Synthesis general}

Progress of the reaction was monitored by thin layer chromatography $(0.25 \mathrm{~mm}$ thick precoated silica plates: Merck Fertigplatten Kieselgel 60F254), while purification was effected by silica gel column chromatography (Merck Kieselgel 60; 230-400 mesh). Light petroleum refers to solvent boiling in the range 40-60 ${ }^{\circ} \mathrm{C}$. 2-Bromo-5cyanothiophene, 2-bromo-5-formylthiophene, 2-formylthiophene boronic acid and 5formyl-2,2'-bithiophene were purchased from Aldrich and used as received. The synthesis of 5'-ethoxy-5-formyl-2,2'-bithiophene $\mathbf{1 b}$ has been described elsewhere. ${ }^{1}$

NMR spectra were obtained on a Varian Unity Plus Spectrometer at an operating frequency of $300 \mathrm{MHz}$ for ${ }^{1} \mathrm{H} \mathrm{NMR}$ and $75.4 \mathrm{MHz}$ for ${ }^{13} \mathrm{C}$ NMR using the solvent peak as internal reference. The solvents are indicated in parenthesis before the chemical shift values ( $\delta$ relative to TMS). Mps were determined on a Gallenkamp apparatus and are uncorrected. Infrared spectra were recorded on a BOMEM MB 104 spectrophotometer. UV-vis absorption spectra $(200-800 \mathrm{~nm})$ were obtained using a Shimadzu UV/2501PC spectrophotometer. Mass spectrometry analyses were performed at the C.A.C.T.I. Unidad de Espectrometria de Masas of the University of Vigo, Spain. Elemental analysis was carried out on a Leco CHNS-932.

\subsection{Procedure for the synthesis of aldehyde 1c through Suzuki cross-coupling}

2-Bromo-5-cyanothiophene $(1.0 \mathrm{mmol})$ was coupled with 2-formylthiophene boronic acid $(1.4 \mathrm{mmol})$, in a mixture of $\mathrm{DME}(15 \mathrm{~mL})$ and aqueous $2 \mathrm{M} \mathrm{Na}_{2} \mathrm{CO}_{3}(1 \mathrm{~mL})$ and $\mathrm{Pd}\left(\mathrm{PPh}_{3}\right)_{4}(3 \mathrm{~mol} \%)$ at $80{ }^{\circ} \mathrm{C}$ under a argon atmosphere. The reaction was followed by TLC until completion (12 h). After cooling the mixture was filtered. Ethyl acetate (50 $\mathrm{mL})$ and a saturated solution of $\mathrm{NaCl}(20 \mathrm{~mL})$ were added and the phases were separated. The organic phase was washed with water $(3 \times 50 \mathrm{~mL})$ and with a solution of $\mathrm{NaOH}$ (10\%) (1 x $20 \mathrm{~mL})$. The organic phase was dried $\left(\mathrm{MgSO}_{4}\right)$, filtered and solvent removal gave the crude coupled compound which was purified by column chromatography on silica with increasing amounts of diethyl ether in light petroleum as eluent, affording the pure product 1c. 


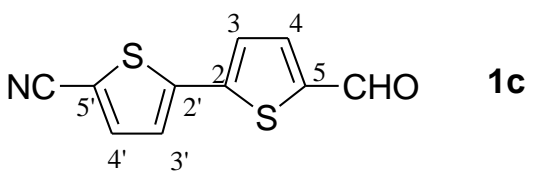

5'-cyano-5-formyl-2,2'-bithiophene 1c. Brown solid (61\%). Mp: 179.5-180.8 ${ }^{\circ} \mathrm{C}$. UV (EtOH): $\lambda_{\max } \mathrm{nm}\left(\varepsilon / \mathrm{M}^{-1} \mathrm{~cm}^{-1}\right) 454.5$ (29730), 300.0 (6000), 277.0 (10390). IR (KBr) $v$ $2219(\mathrm{CN}), 1657(\mathrm{CO}), 1432,1286,1221,1060,884,810,754 \mathrm{~cm}^{-1} .{ }^{1} \mathrm{H} \mathrm{NMR}\left(\mathrm{CDCl}_{3}\right) \delta$ 7.32 (d, $\left.1 \mathrm{H}, J=3.9 \mathrm{~Hz}, 3^{\prime}-\mathrm{H}\right), 7.37$ (d, $\left.1 \mathrm{H}, J=3.9 \mathrm{~Hz}, 3-\mathrm{H}\right), 7.59$ (d, 1H, J=3.9 Hz, 4-H), $7.72\left(\mathrm{~d}, 1 \mathrm{H}, J=3.9 \mathrm{~Hz}, 4^{\prime}-\mathrm{H}\right), 9.93$ (s, 1H, CHO). ${ }^{13} \mathrm{C} \mathrm{NMR}\left(\mathrm{CDCl}_{3}\right) \delta 110.05\left(\mathrm{C} 5^{\prime}\right)$, 113.50 (CN), 125.63 (C3), 126.38 (C3'), 136.82 (C4), 138.33 (C4'), 142.68 (C2'), 143.45 (C2), 143.83 (C5), 182.47 (CHO). MS (EI) m/z (\%): 220 (9), $219\left(\mathrm{M}^{+}+1,17\right), 218\left(\mathrm{M}^{+}\right.$, 91), 217 (100), 146 (51), 118 (6), 85 (53), 83 (84). HRMS: (EI) $\mathrm{m} / z$ (\%) for $\mathrm{C}_{10} \mathrm{H}_{5} \mathrm{NOS}_{2}$; calcd 218.9813; found 218.9817.

\subsection{General procedure for the synthesis of compounds $2 \mathrm{a}-\mathrm{c}$}

i) Preparation of the imines

The aldehydes 1a-c $(0.20 \mathrm{mmol})$ and 1,2-diaminoanthraquinone $(0.24 \mathrm{mmol})$ were dissolved separately in ethanol $(4 \mathrm{~mL} / \mathrm{mmol})$. The ethanolic solution of aldehyde and formic acid $(0.04 \mathrm{~mL} / \mathrm{mmol}$ of aldehyde) was added to the solution of 1,2diaminoanthraquinone heated at reflux. The reaction mixture was heated under reflux overnight.

\section{ii) Cyclisation of the imines}

After cooling, the ethanolic solution was evaporated and the crude imine was dissolved in a small volume of acetic acid ( $5 \mathrm{~mL} / \mathrm{mmol}$ of imine). To this solution, lead tetraacetate was added $(0.20 \mathrm{mmol})$ and the mixture was stirred overnight at room temperature. Addition of water to the reaction mixture gave a solid which was isolated by filtration and purified by recrystalization from diethyl ether/chloroform. 


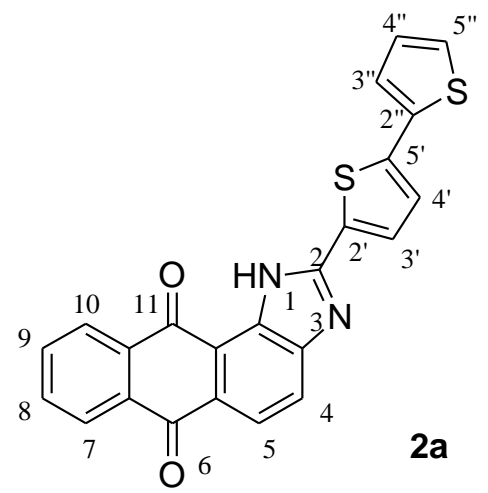

2-(2',2'-bithienyl)-1H-anthra[1,2- $d]$ imidazole-6,11-dione 2a. Dark red solid (92\%). Mp: 249.1-251.6 ${ }^{\circ} \mathrm{C}$. UV ( $\left.\mathrm{CH}_{3} \mathrm{CN}\right): \lambda_{\max } \mathrm{nm}\left(\varepsilon / \mathrm{M}^{-1} \mathrm{~cm}^{-1}\right): 262$ (25741); 288(sh) (14776); 342 (18609); 446 (18224). IR (KBr) v 1657 (CO br), 1579, 1530, 1488, 1424, 1326, 1289, 1156, 1063, 1007, 926, 832, 807, $714 \mathrm{~cm}^{-1} .{ }^{1} \mathrm{H}$ NMR (DMSO-d 6 ) $\delta 7.14(\mathrm{~m}, 1 \mathrm{H}$, 4"-H), 7.43 (d, 1H, J=3.9 Hz, 3'-H), 7.47 (dd, 1H, J=3.4 and 1.2 Hz, 3"-H), 7.61 (dd, 1H, $J=4.9$ and $1.2 \mathrm{~Hz}, 5 "-\mathrm{H}), 7.90-7.93$ (m, 2H, 8-H and 9-H), 7.89-8.06 (m, 2H, 4-H and 5H), 8.17-8.23 (m, 2H, 7-H and 10-H), 8.46 (d, 1H, J=3.6 Hz, 4'-H), 13.47 (s, 1H, NH). ${ }^{13} \mathrm{C}$ NMR (DMSO-d $\left.{ }_{6}\right) \delta 118.42,121.20,124.04,125.14,125.41,126.19,126.75,126.81$, $127.87,128.65,130.79,131.27,133.01,133.11,134.23,134.41,135.73,140.58,149.10$, 182.24, 183.06. MS (FAB) $m / z(\%): 413\left([\mathrm{M}+\mathrm{H}]^{+}, 22\right), 412\left(\mathrm{M}^{+}, 9\right), 307$ (39), 289 (13), 288 (10), 155 (31), 154 (100). HRMS: (FAB) $m / z$ (\%) for $\mathrm{C}_{23} \mathrm{H}_{12} \mathrm{~N}_{2} \mathrm{O}_{2} \mathrm{~S}_{2}$; calcd 413.0418; found 413.0415 .

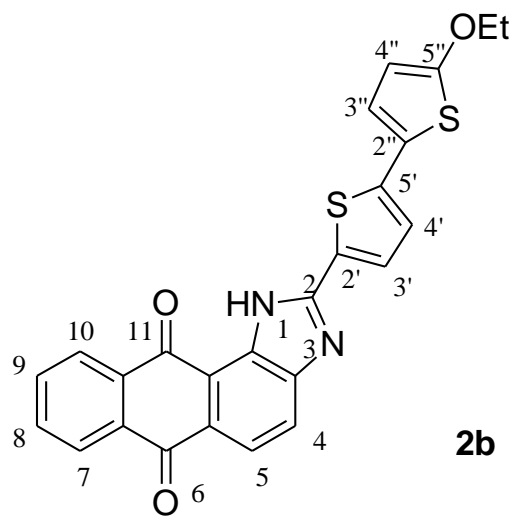

2-(5'-Ethoxy-2',2"'-bithienyl)-1H-anthra[1,2-d]imidazole-6,11-dione 2b. Dark red solid (67\%). Mp: $227.2-230.3{ }^{\circ} \mathrm{C}$. UV $\left(\mathrm{CH}_{3} \mathrm{CN}\right): \lambda_{\max } \mathrm{nm}\left(\varepsilon / \mathrm{M}^{-1} \mathrm{~cm}^{-1}\right): 263(15143) ; 363$ (8137); 450 (8945). IR (liquid film) v 3383 (NH), 1667 (CO br), 1583, 1503, 1468, 1376, 1291, 1154, 1046, 1006, 930, 894, 839, 809, 793, $719 \mathrm{~cm}^{-1} .{ }^{1} \mathrm{H}$ NMR (DMSO-d 6 ) $\delta 1.34$ 
(t, $\left.3 \mathrm{H}, J=6.9 \mathrm{~Hz}, \mathrm{OCH}_{2} \mathrm{CH}_{3}\right), 4.12\left(\mathrm{q}, 2 \mathrm{H}, J=6.9 \mathrm{~Hz}, \mathrm{OCH}_{2} \mathrm{CH}_{3}\right), 6.30(\mathrm{~d}, 1 \mathrm{H}, J=4.2 \mathrm{~Hz}$, 4"-H), 7.08 (d, 1H, J=3.9 Hz, 3"-H), 7.16 (d, 1H, J=3.9 Hz, 3’-H), 7.87-7.89 (m, 2H, 8-H and 9-H), 7.94-8.01 (m, 2H, 4-H and 5-H), 8.14-8.19 (m, 2H, 7- $\mathrm{H}$ and 10-H), 8.37 (br s, 1H, 4'-H), 13.32 (s, 1H, NH). ${ }^{13} \mathrm{C}$ NMR (DMSO-d ${ }_{6}$ ) $\delta 14.44,69.37,106.04,121.18$, $121.69,123.29,123.65,124.01,126.13,126.70,127.71,129.12,131.92,132.92,134.15$, 141.45, 149.17, 152.54, 164.89, 182.11, 182.99. MS (FAB) $\mathrm{m} / z(\%): 457\left([\mathrm{M}+\mathrm{H}]^{+}, 50\right)$, 456 ( $\mathrm{M}^{+}, 31$ ), 426 (13), 307 (29), 289 (17), 155 (32), 154 (100). HRMS: (FAB) m/z (\%) for $\mathrm{C}_{25} \mathrm{H}_{16} \mathrm{~N}_{2} \mathrm{O}_{3} \mathrm{~S}_{2}$; calcd 457.0681; found 457.0681.

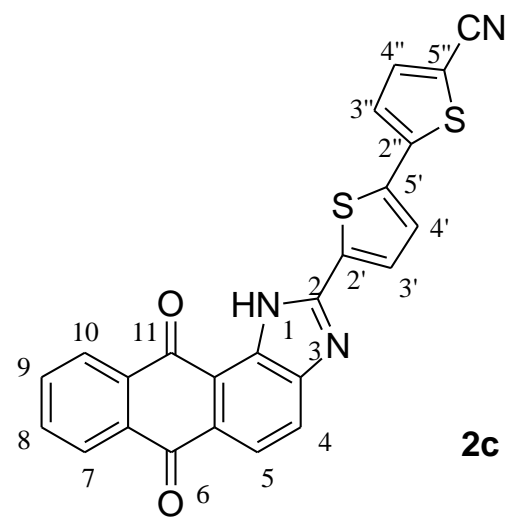

2-(5"-Cyano-2',2"-bithienyl)-1H-anthra[1,2-d]imidazole-6,11-dione 2c. Dark brown solid (68\%). Decomposition at $\mathrm{T}>320{ }^{\circ} \mathrm{C}$. UV $\left(\mathrm{CH}_{3} \mathrm{CN}\right): \lambda_{\max } \mathrm{nm}\left(\varepsilon / \mathrm{M}^{-1} \mathrm{~cm}^{-1}\right): 261$ (26830); 346 (16645); 410 (15290); 448(sh) (13115); 531 (7675). IR (liquid film) v 3490 (NH), $2215(\mathrm{CN}), 1663$ (CO br), 1584, 1565, 1529, 1490, 1376, 1325, 1187, 1156, 1062, 1006, 965, 846, 795, $716 \mathrm{~cm}^{-1} .{ }^{1} \mathrm{H}$ NMR (DMSO-d 6 ) $\delta 7.64\left(\mathrm{~d}, 1 \mathrm{H}, J=3.9 \mathrm{~Hz}, 3^{\prime}-\mathrm{H}\right), 7.70$ (d, 1H, J=3.9 Hz, 3"-H), $7.93-7.96$ (m, 2H, 8-H and 9-H), 8.00 (d, 1H, J=3.6 Hz, 4'-H), 8.08-8.10 (m, 2H, 4-H and 5-H), 8.21-8.27 (m, 2H, 7-H and 10-H), $8.56(\mathrm{~d}, 1 \mathrm{H}, J=3.9$ $\left.\mathrm{Hz}, 4^{\prime \prime}-\mathrm{H}\right), 13.64$ (s, 1H, NH). MS (FAB) m/z (\%): 438 ([M+H] $\left.]^{+}, 13\right), 437\left(\mathrm{M}^{+}, 12\right), 307$ (44), 289 (18), 155 (31), 154 (100). HRMS: (FAB) $m / z$ (\%) for $\mathrm{C}_{24} \mathrm{H}_{11} \mathrm{~N}_{3} \mathrm{O}_{2} \mathrm{~S}_{2}$; calcd 438.0371; found 438.0377 . 
2. ${ }^{1} \mathrm{H}$ and ${ }^{13} \mathrm{C}$ NMR spectra of compounds $1 \mathrm{c}$ and $2 \mathrm{a}-\mathrm{c}$

${ }^{1}$ H NMR data for compound $\mathbf{1 c}$<smiles>N#Cc1ccc(-c2ccc(C=O)s2)s1</smiles>

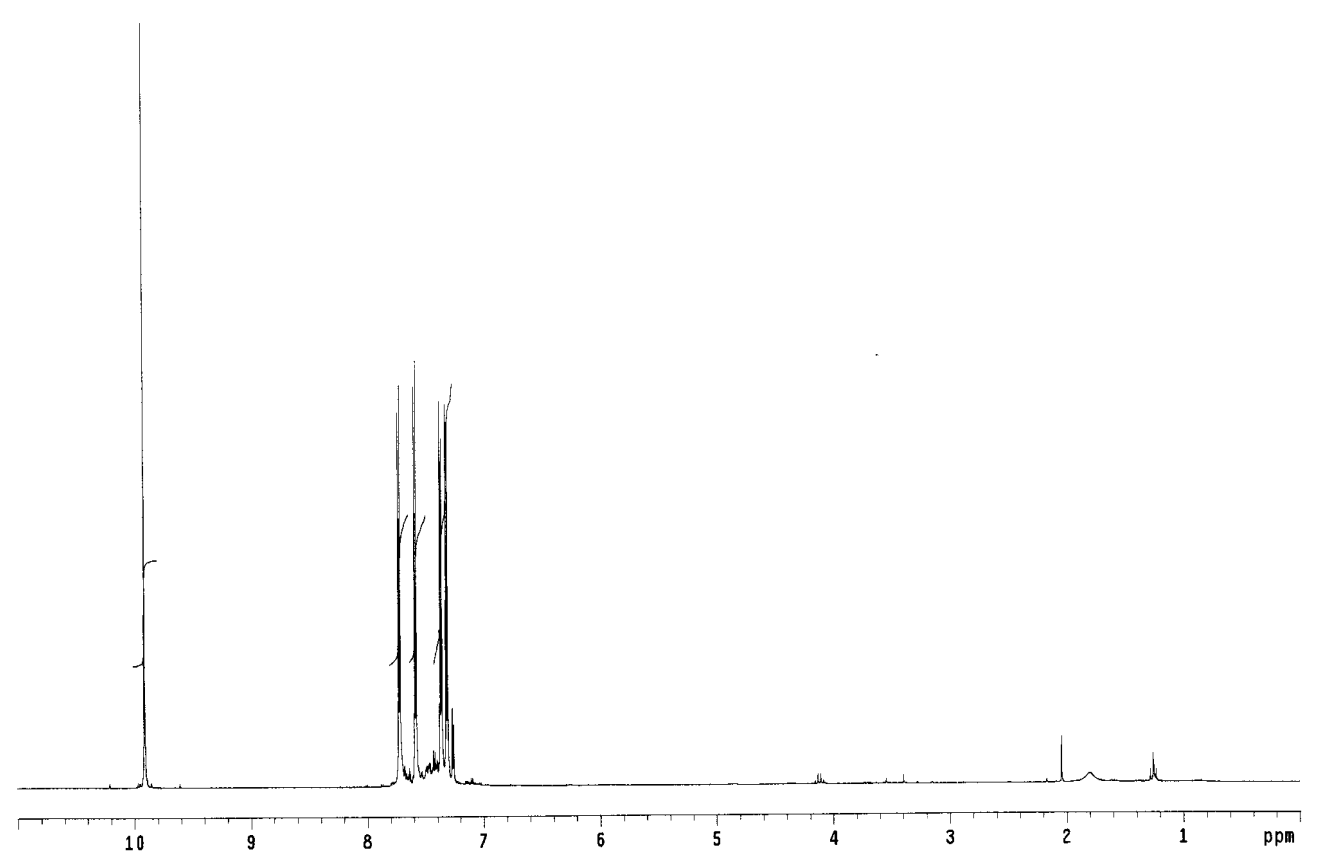

Expansion of aromatic zone

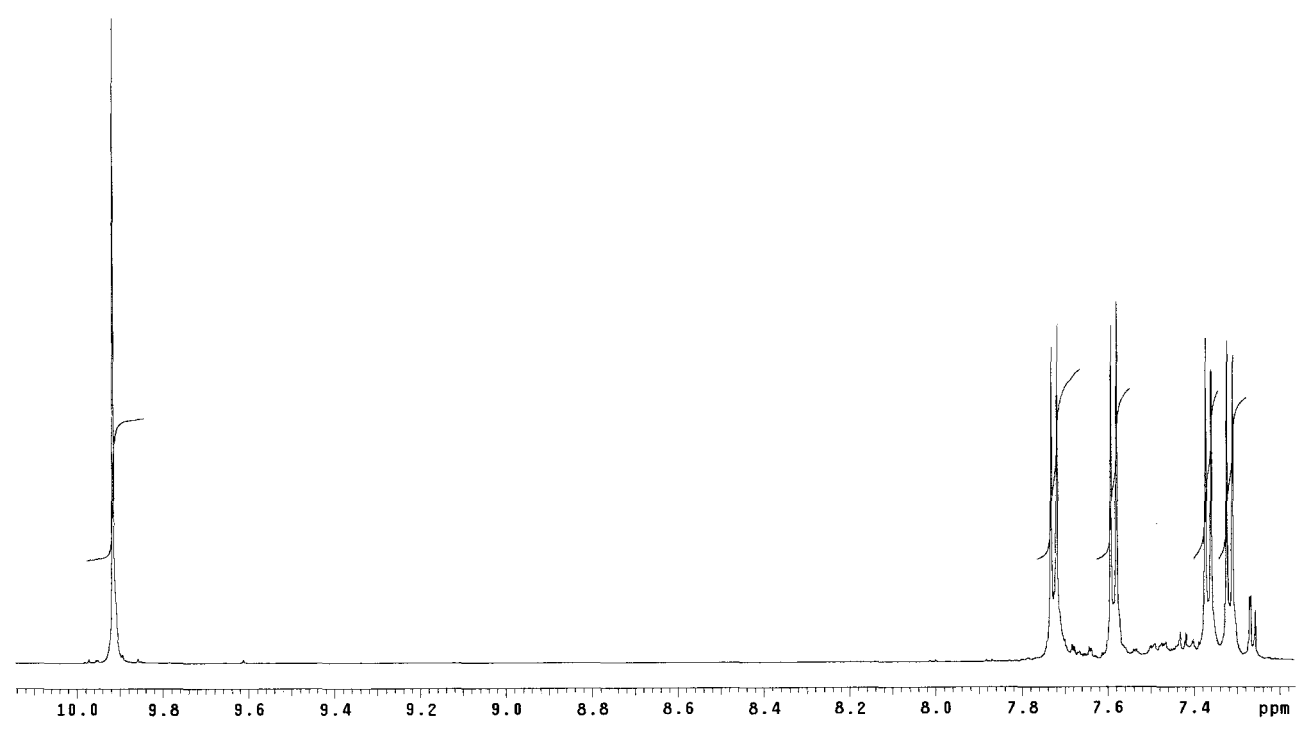


${ }^{13} \mathrm{C}$ NMR data for compound $\mathbf{1 c}$
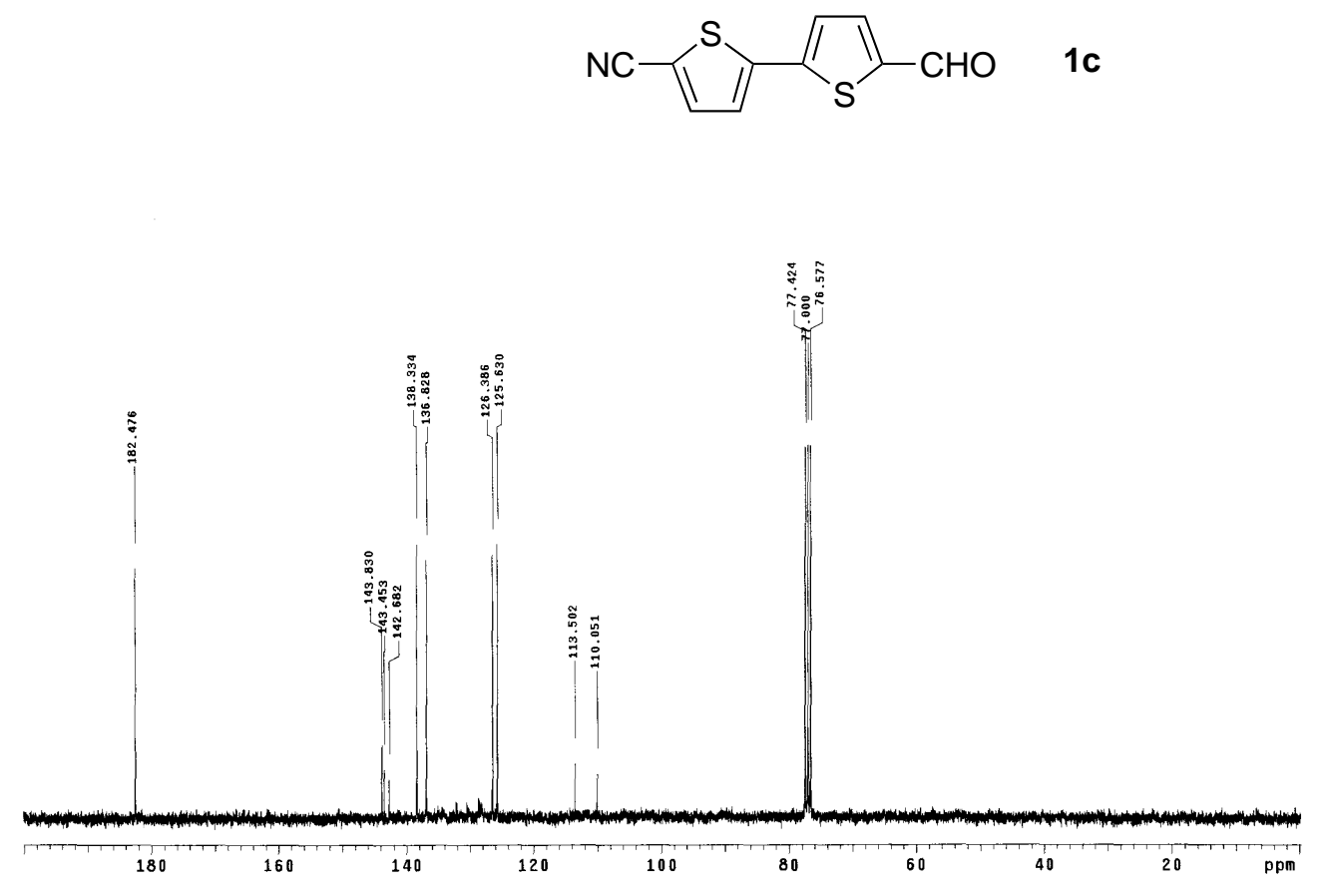

Expansion of aromatic zone

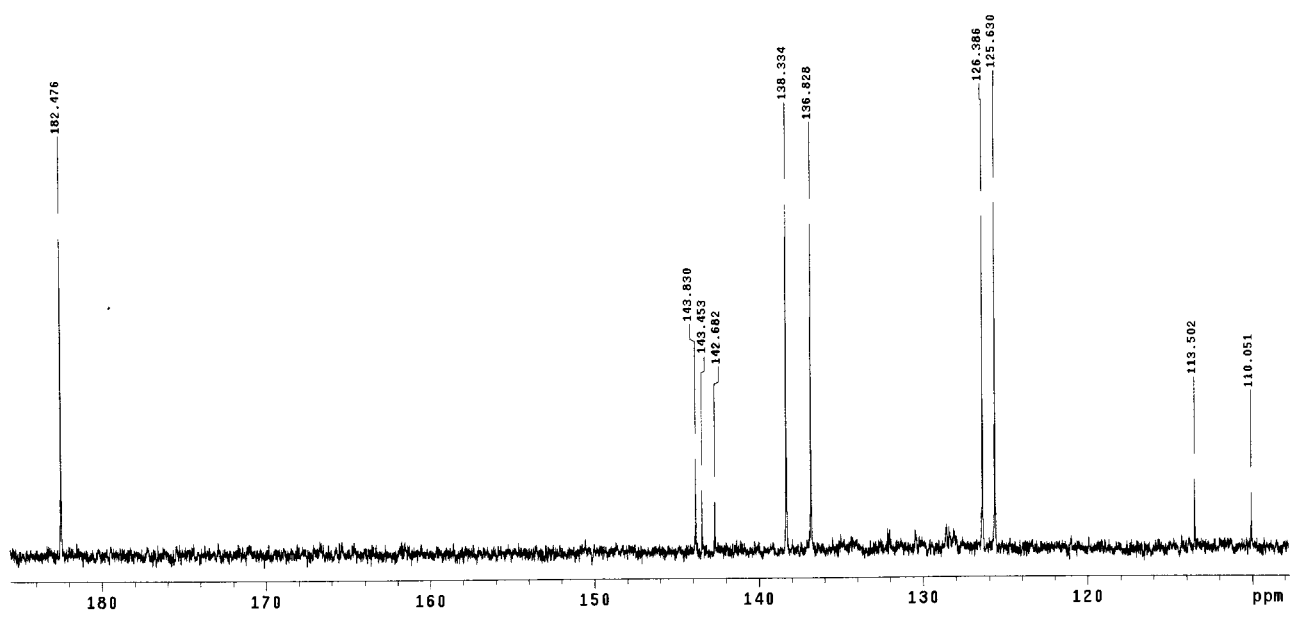




\section{${ }^{1}$ H NMR data for compound $\mathbf{2 a}$}

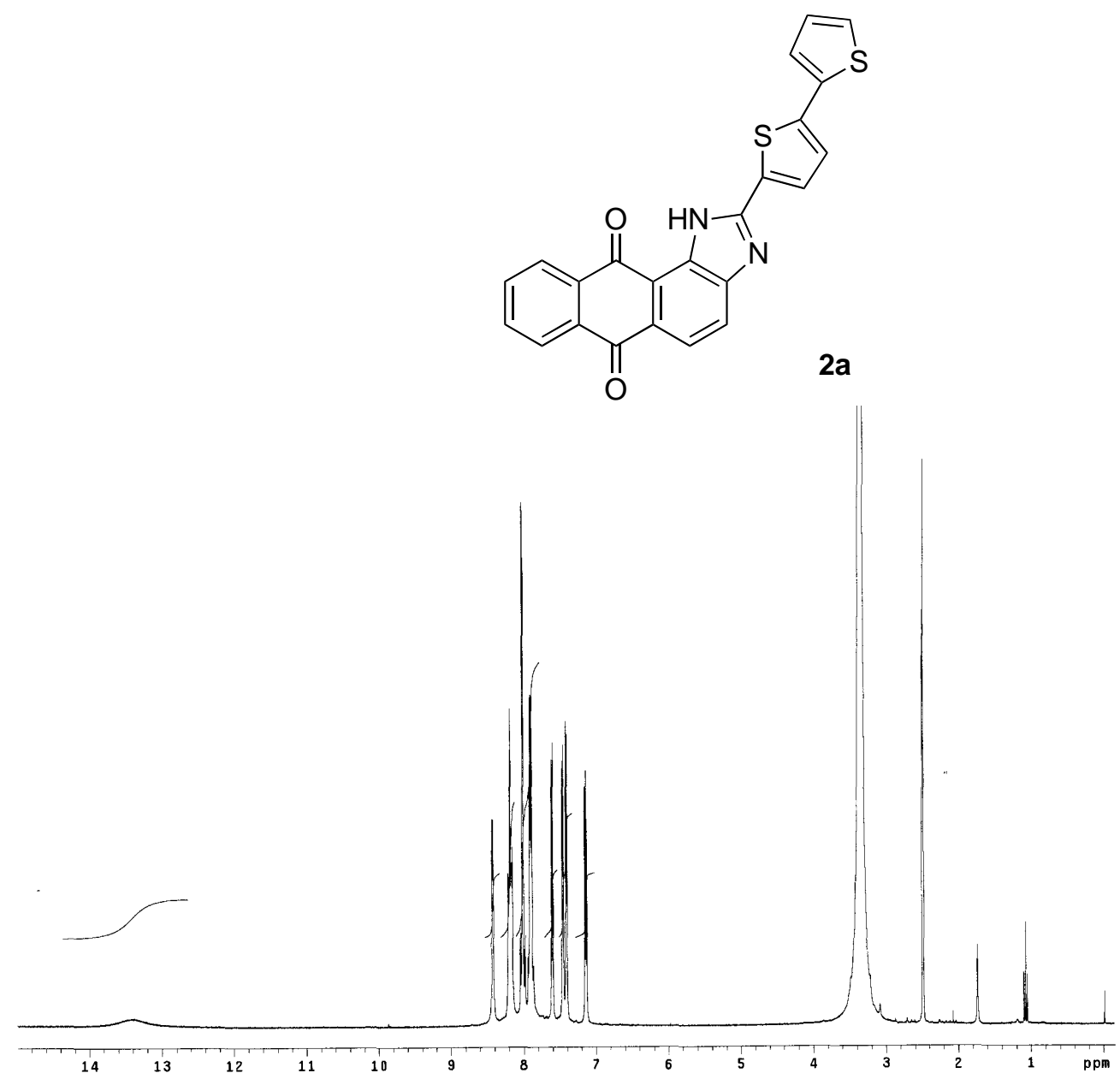

\section{Expansion of aromatic zone}

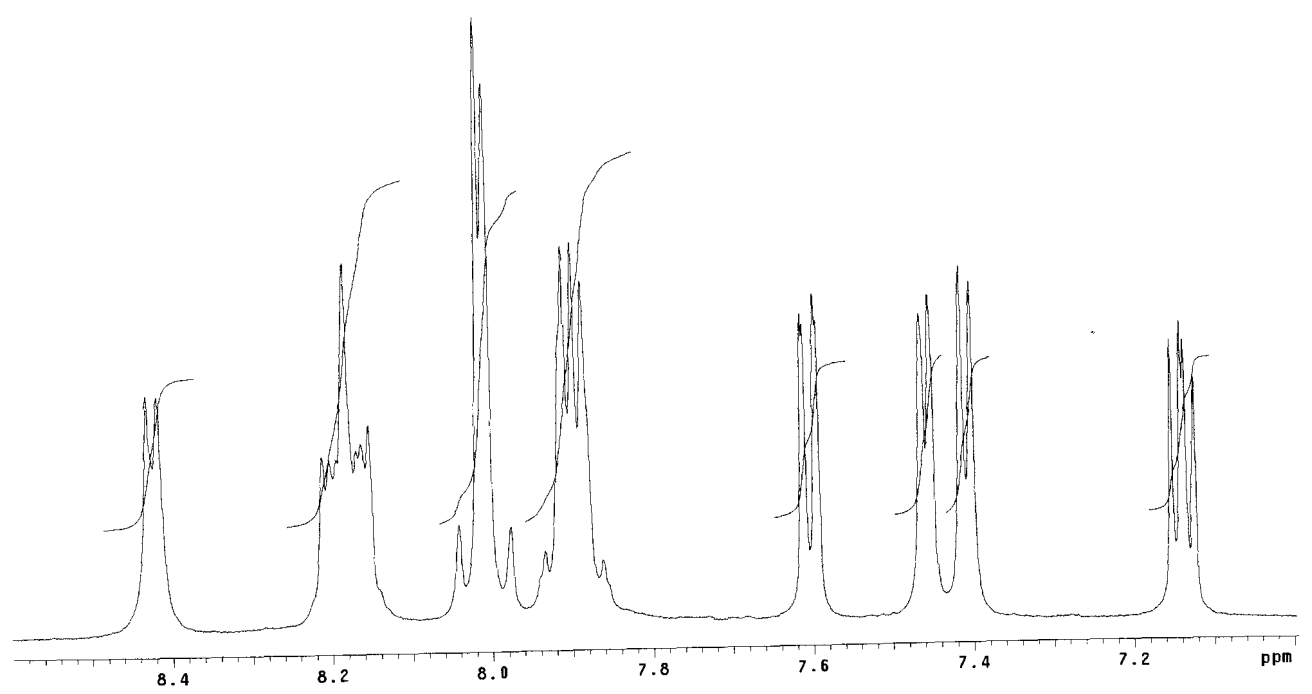


${ }^{13} \mathrm{C}$ NMR data for compound 2a<smiles>O=C1c2ccccc2C(=O)c2c1ccc1nc(-c3ccc(-c4cccs4)s3)[nH]c21</smiles>

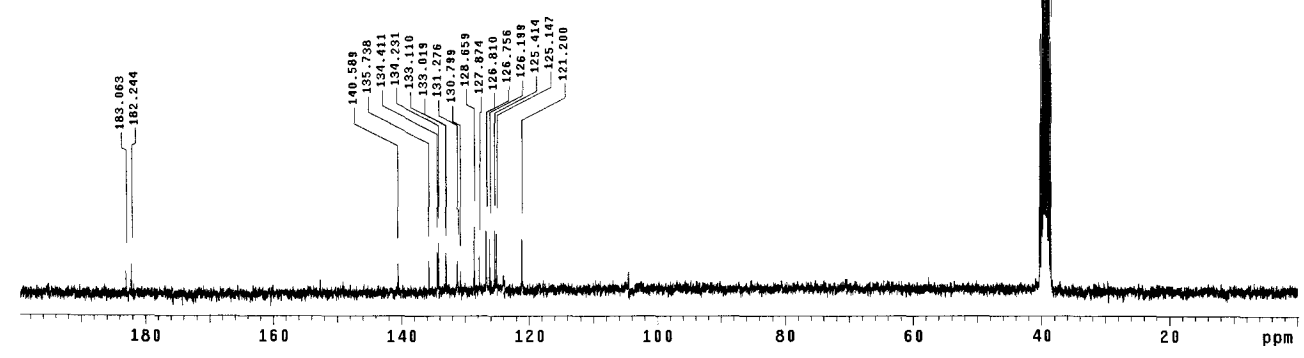

Expansion of aromatic zone

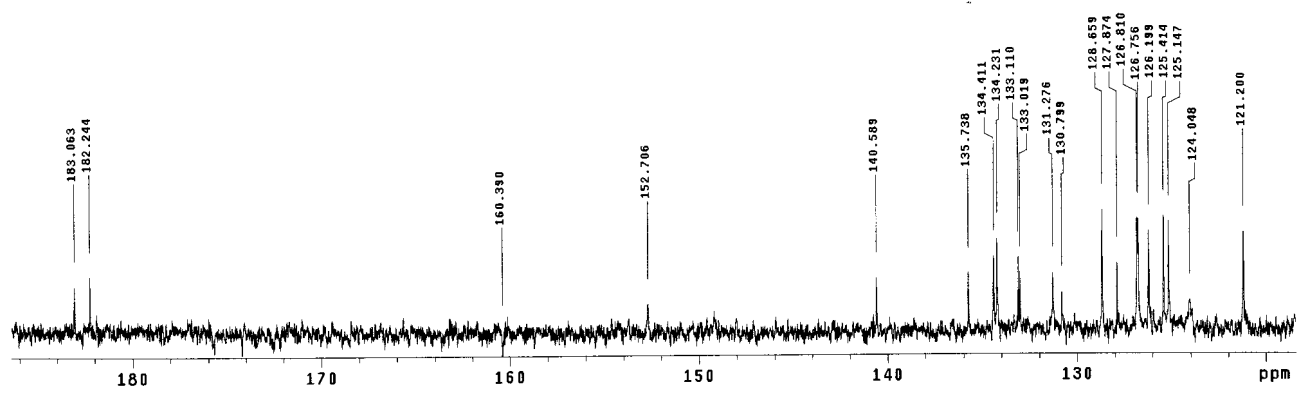




\section{${ }^{1}$ H NMR data for compound $\mathbf{2 b}$}
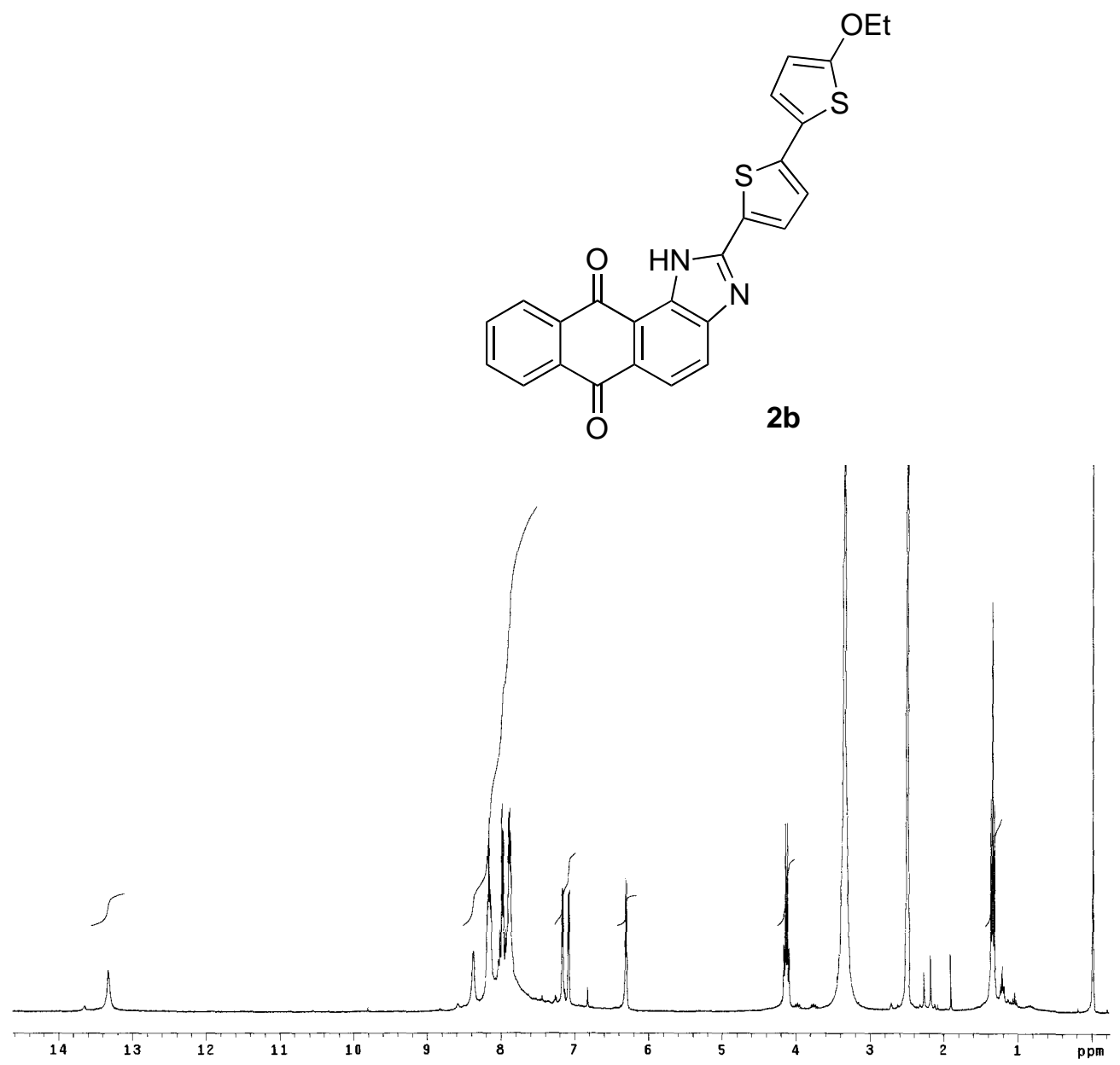

\section{Expansion of aromatic zone}

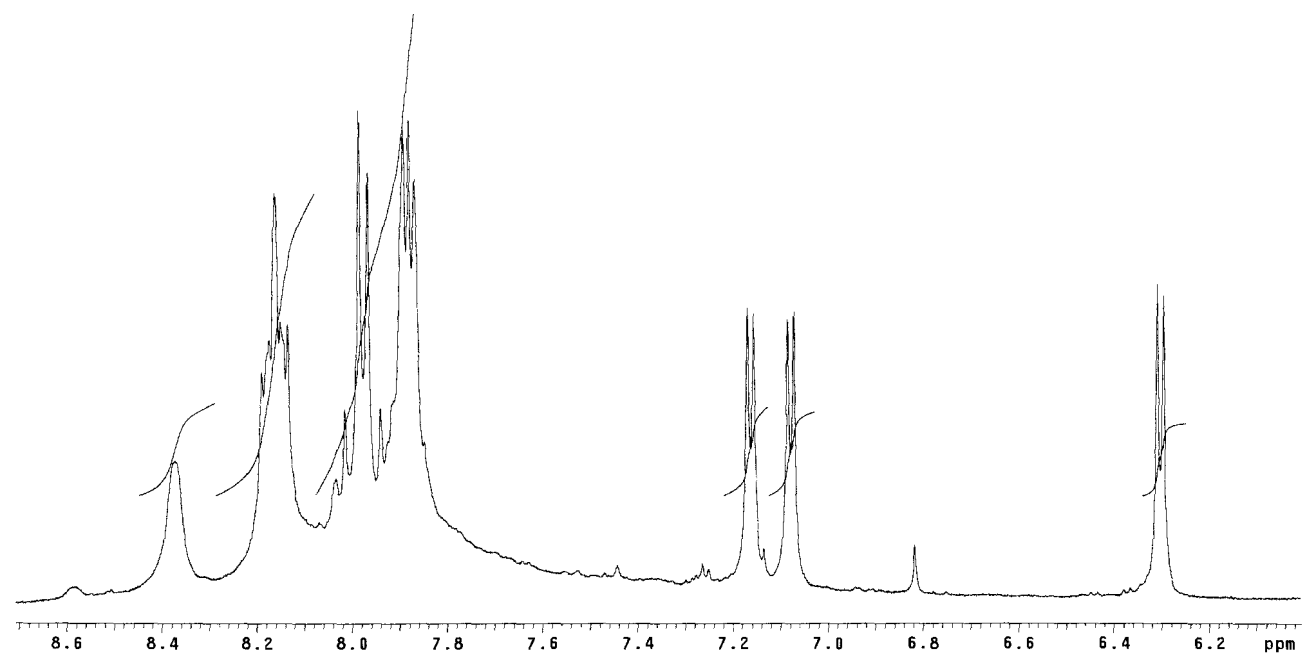


${ }^{13} \mathrm{C}$ NMR data for compound $\mathbf{2 b}$<smiles>CCOc1ccc(-c2ccc(-c3nc4ccc5c(c4[nH]3)C(=O)c3ccccc3C5=O)s2)s1</smiles>

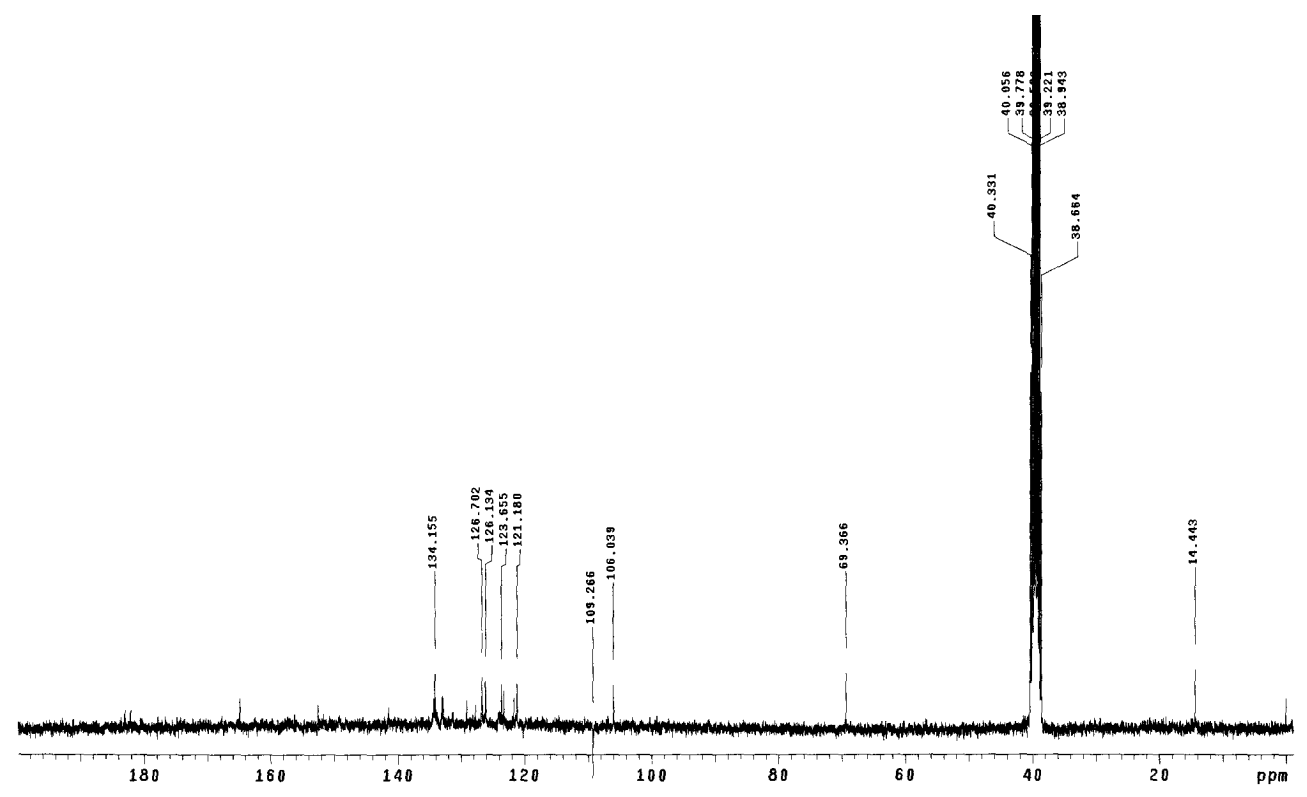

Expansion of aromatic zone

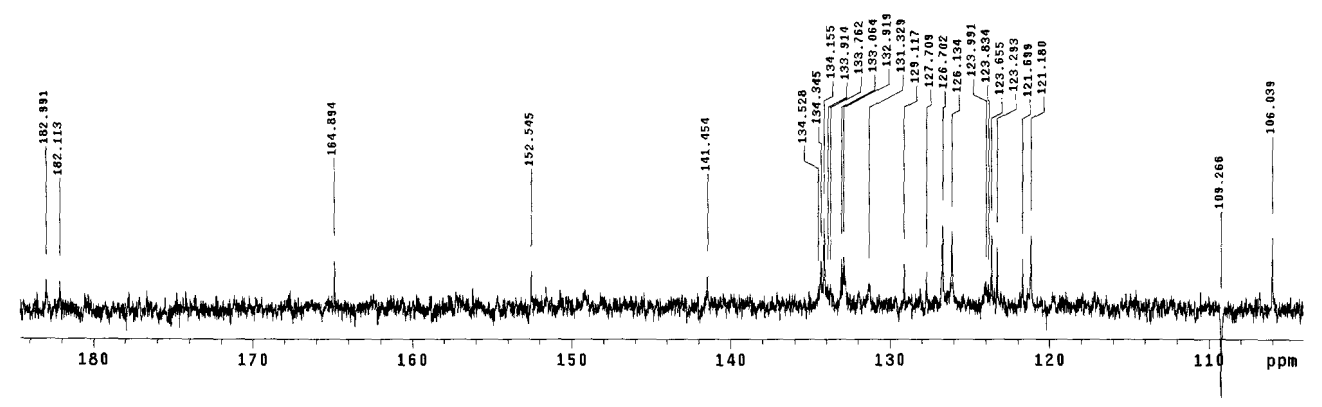


${ }^{1} \mathrm{H}$ NMR data for compound $\mathbf{2 c}$<smiles>N#Cc1ccc(-c2ccc(-c3nc4ccc5c(c4[nH]3)C(=O)c3ccccc3C5=O)s2)s1</smiles>

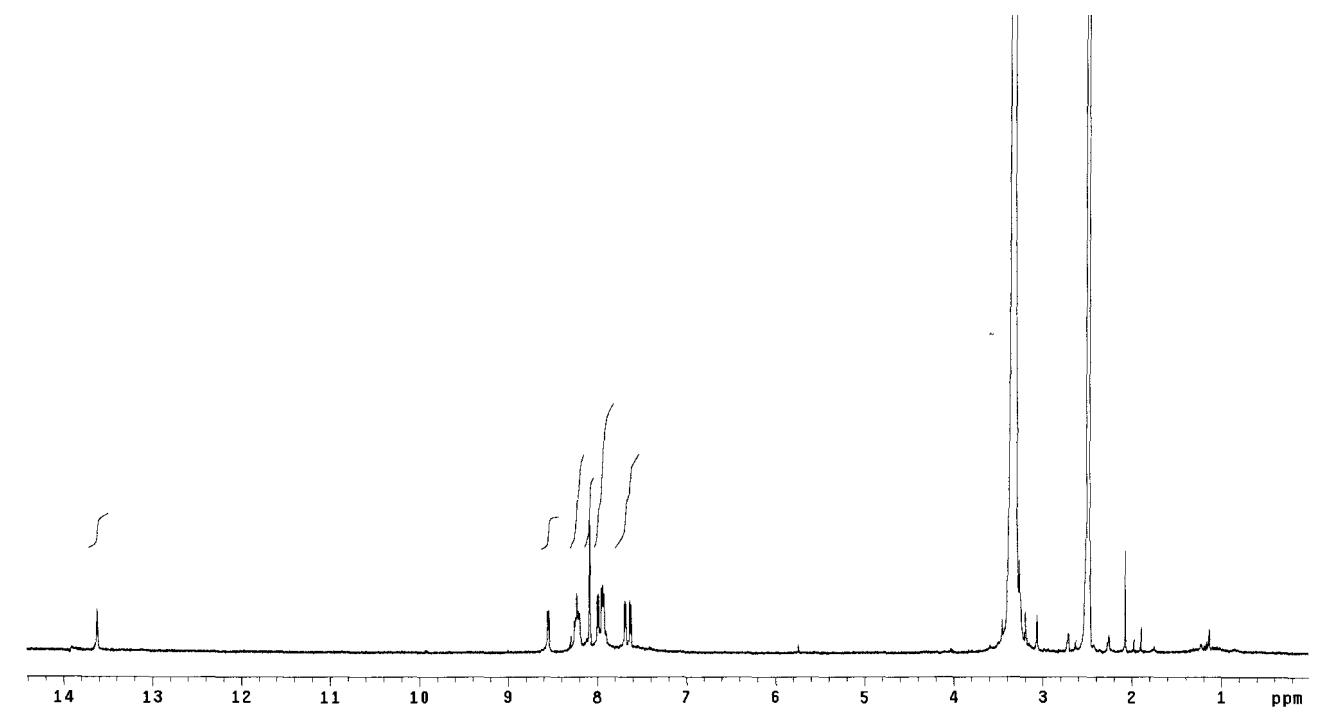

Expansion of aromatic zone

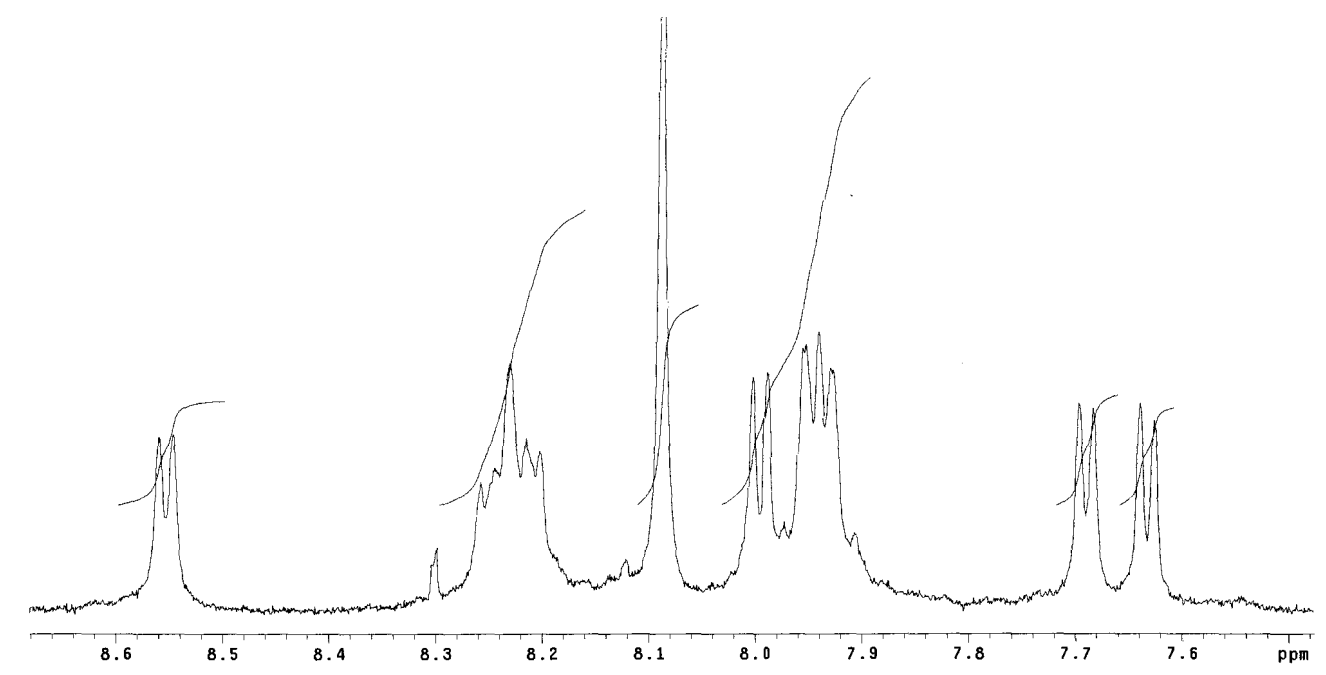




\section{Spectrophotometric and spectrofluorimetric studies of compounds 2a-c}

\subsection{General}

UV/Vis spectra were performed using a Perkin Elmer Lambda 35 spectrophotometer and fluorescence spectra on a Perkin Elmer LS45. The linearity of the fluorescence emission $v s$. concentration was checked in the concentration range used $\left(10^{-4}-10^{-6} \mathrm{M}\right)$. A correction for the absorbed light was performed when necessary. All spectrofluorimetric titrations were performed as follows: stock solutions of compounds $2 \mathbf{a}-\mathbf{c}\left(\mathrm{ca} .10^{-3} \mathrm{M}\right)$ were prepared with $\mathrm{CH}_{3} \mathrm{CN}$ UVA-sol and used in the preparation of titration solutions by appropriate dilution. Titration of the compounds 2a-c was carried out by addition of microliter amounts of standard solutions of the ions (cations or anions) in acetonitrile. All anions $\left(\mathrm{F}^{-}, \mathrm{Cl}^{-}, \mathrm{Br}^{-}\right.$and $\left.\mathrm{I}^{-}\right)$were used as their tetrabutylammonium salts. The acidity of the acetonitrile solutions was adjusted by addition of $\mathrm{HBF}_{4}$, methanesulphonic acid, triethylamine and tetrabutylamonium hydroxide. Luminescence quantum yields were measured using as standard a solution of quinine sulfate in sulfuric acid $(0.1 \mathrm{M})\left(\Phi_{\mathrm{F}}=\right.$ 0.54). ${ }^{2} \mathrm{Cu}\left(\mathrm{CF}_{3} \mathrm{SO}_{3}\right)_{2}, \mathrm{Zn}\left(\mathrm{CF}_{3} \mathrm{SO}_{3}\right)_{2}$, and $\mathrm{Hg}\left(\mathrm{CF}_{3} \mathrm{SO}_{3}\right)_{2}$ were purchased from Alfa Aesar and used without further purification.

\subsection{Proton sensing ability of compounds 2a-c}

$\mathrm{UV}$-vis absorption spectra of 2a-c in $\mathrm{CH}_{3} \mathrm{CN}$ solution upon addition of increasing amounts of methanesulphonic acid. Inset: equivalents of acid $[2] /\left[\mathrm{H}^{+}\right]$.

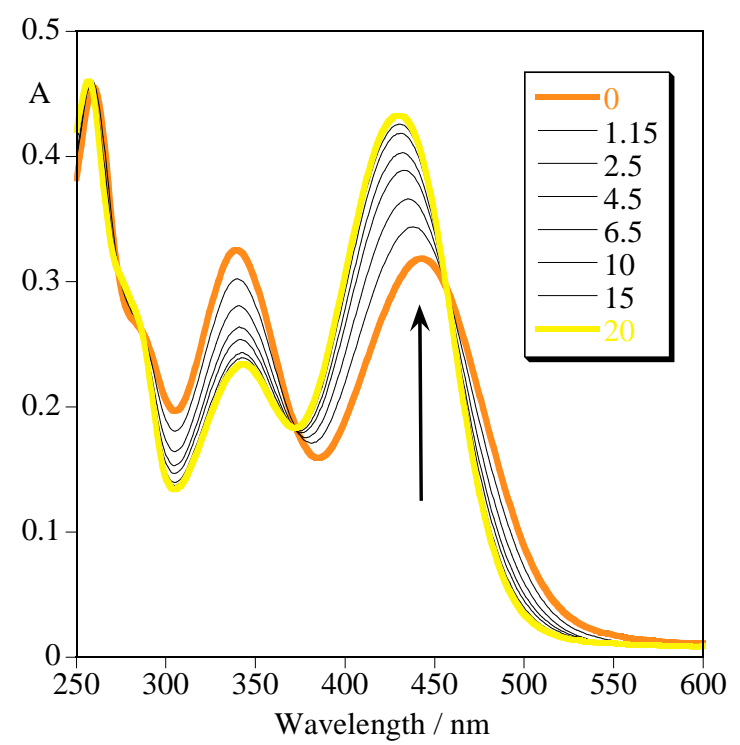

Figure S1. UV-vis spectral changes of $2 \mathrm{a}$ in $\mathrm{CH}_{3} \mathrm{CN}\left(1.75 \times 10^{-5} \mathrm{M}\right)$ with addition of acid. 


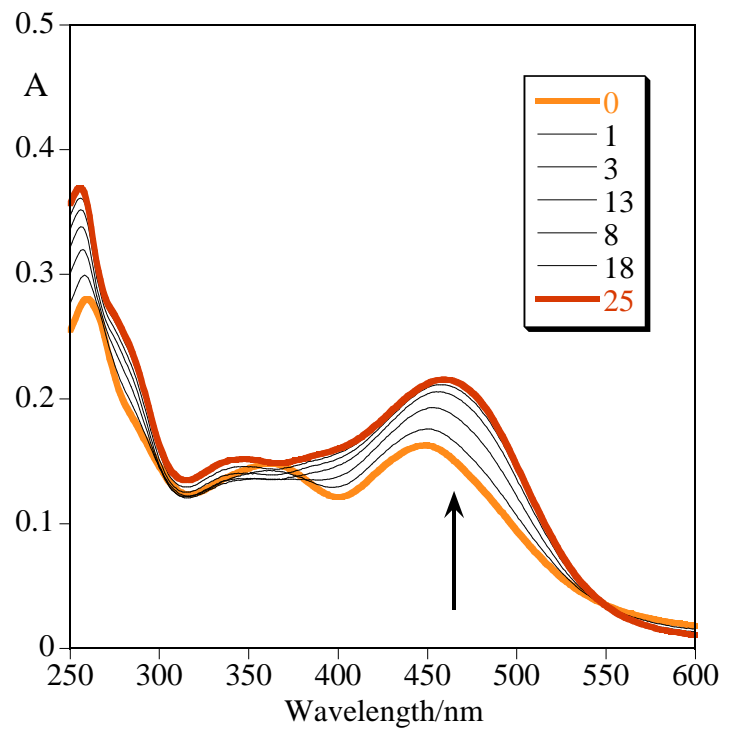

Figure S2. UV-vis spectral changes of $\mathbf{2 b}$ in $\mathrm{CH}_{3} \mathrm{CN}\left(1.80 \times 10^{-5} \mathrm{M}\right)$ with addition of acid.

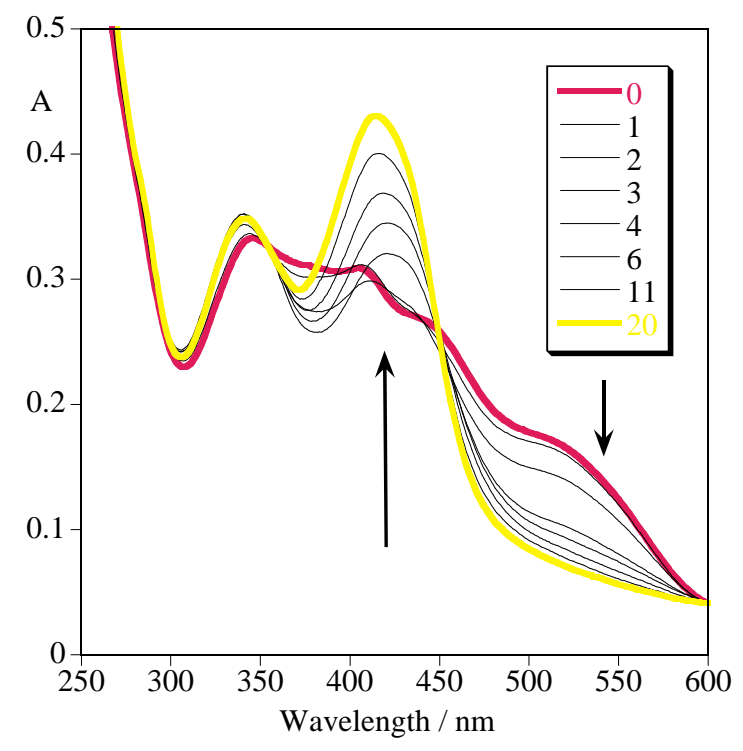

Figure S3. UV-vis spectral changes of $2 \mathbf{c}$ in $\mathrm{CH}_{3} \mathrm{CN}\left(2.00 \times 10^{-5} \mathrm{M}\right)$ with addition of acid. 


\subsection{Basic anions $\left(\mathrm{CN}^{-}, \mathrm{CH}_{3} \mathrm{COO}^{-}\right.$and $\left.\mathrm{H}_{2} \mathrm{PO}_{4}{ }^{-}\right)$sensing ability of compound 2a}

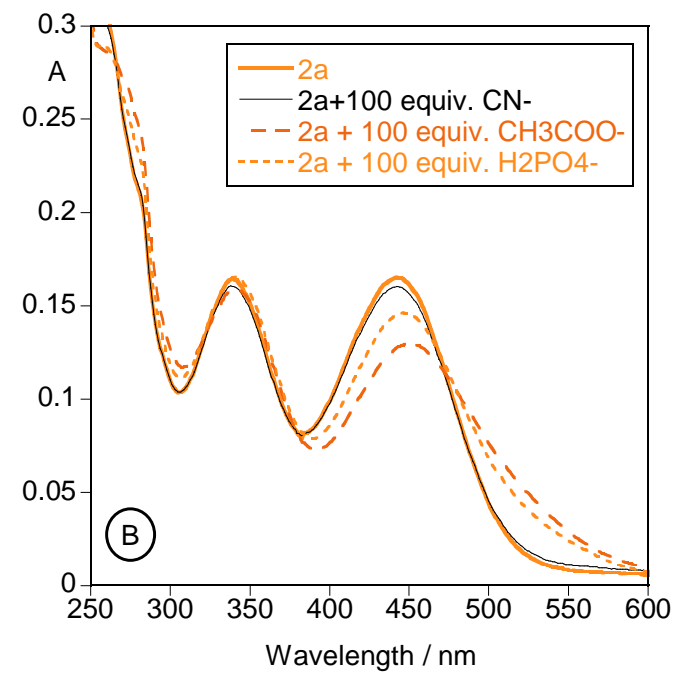

Figure S4. Spectral changes of $2 \mathrm{a}$ in $\mathrm{CH}_{3} \mathrm{CN}\left(1.00 \times 10^{-5} \mathrm{M}\right)$ with the addition of cyanide, acetate and dihydrogen phosphate anions.

\subsection{Halide ion ( $\mathrm{Cl}^{-}, \mathrm{Br}^{-}$and $\left.\mathrm{I}^{-}\right)$sensing ability of compounds $2 \mathrm{a}-\mathrm{c}$}

$\mathrm{UV}$-vis spectrum of 2a-c in $\mathrm{CH}_{3} \mathrm{CN}$ solution upon addition of 20 equivalents of halide ions $\left(\left[(\mathrm{Bu})_{4} \mathrm{~N}\right] \mathrm{Cl} ;\left[(\mathrm{Bu})_{4} \mathrm{~N}\right] \mathrm{Br}\right.$ and $\left.\left[(\mathrm{Bu})_{4} \mathrm{~N}\right] \mathrm{I}\right)$.

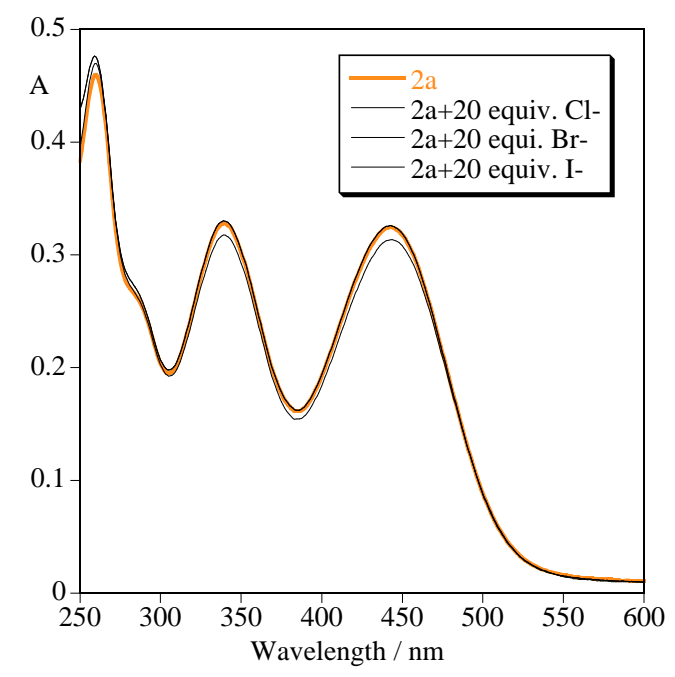

Figure S5. UV-vis spectral changes of $2 \mathbf{a}$ in $\mathrm{CH}_{3} \mathrm{CN}\left(1.75 \times 10^{-5} \mathrm{M}\right)$ with addition of halide ions. 


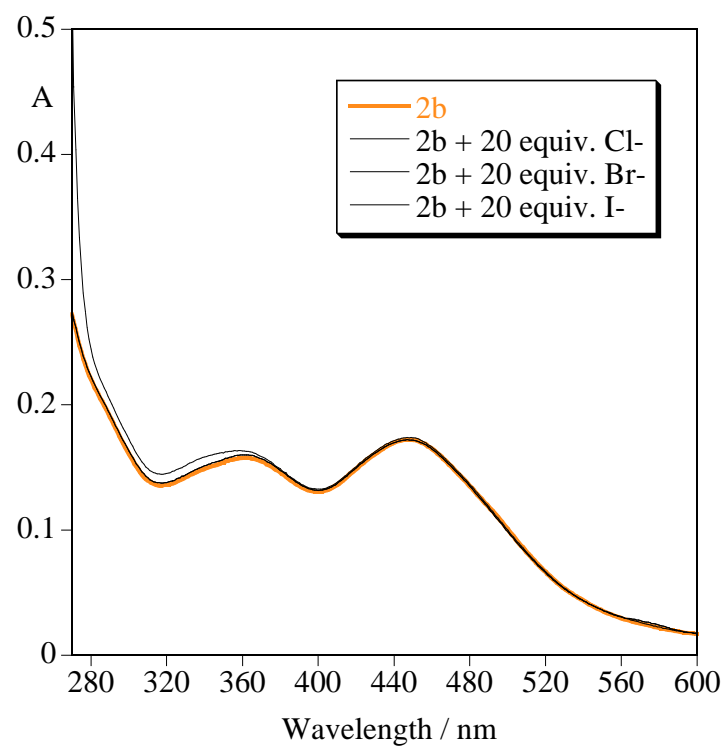

Figure S6. UV-vis spectral changes of $\mathbf{2 b}$ in $\mathrm{CH}_{3} \mathrm{CN}\left(1.80 \times 10^{-5} \mathrm{M}\right)$ with addition of halide ions.

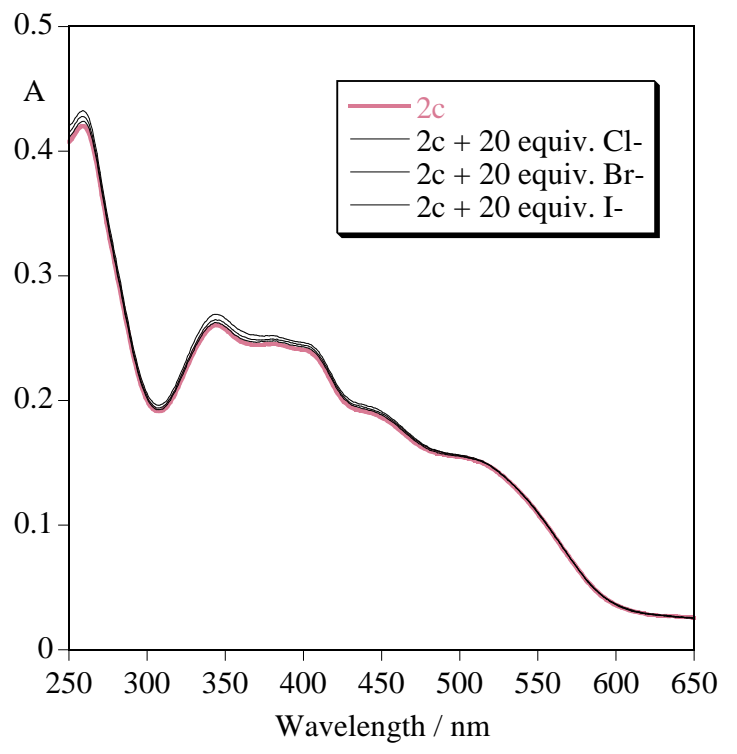

Figure S7. UV-vis spectral changes of $2 \mathbf{c}$ in $\mathrm{CH}_{3} \mathrm{CN}\left(2.00 \times 10^{-5} \mathrm{M}\right)$ with addition of halide ions. 


\subsection{Fluoride ion sensing ability of compounds 2a-c}
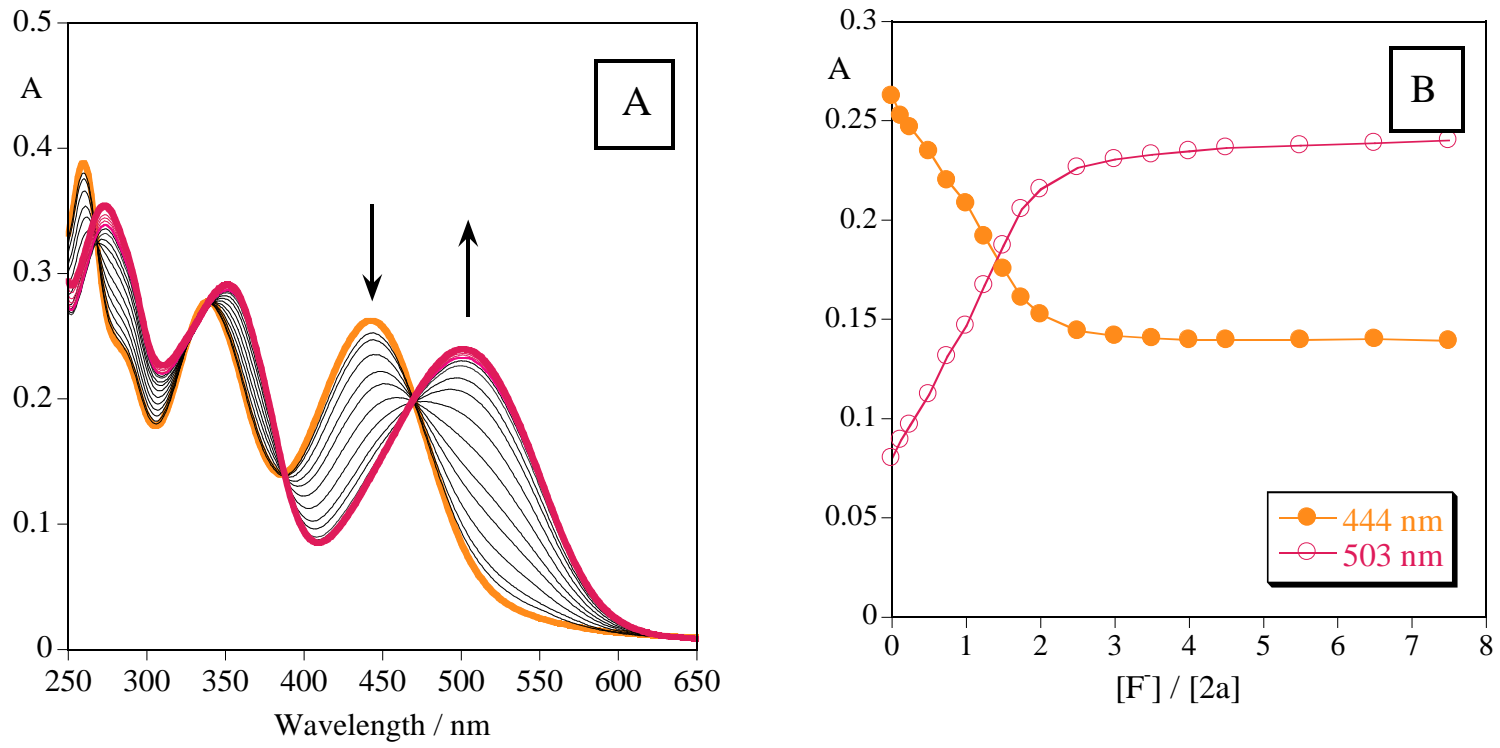

Figure S8. Spectrophotometric titration of an $\mathrm{CH}_{3} \mathrm{CN}$ solution of 2a with a standard $\mathrm{CH}_{3} \mathrm{CN}$ solution of $\left[(\mathrm{Bu})_{4} \mathrm{~N}\right] \mathrm{F}(\mathrm{A})$ and $(\mathrm{B})$ titration profile of $\mathbf{2 a}$ in $\mathrm{CH}_{3} \mathrm{CN}$ with fluoride; Absorptions at $444 \mathrm{~nm}$ and $503 \mathrm{~nm} ;[\mathbf{2 a}]=1.75 \times 10^{-5} \mathrm{M}$.
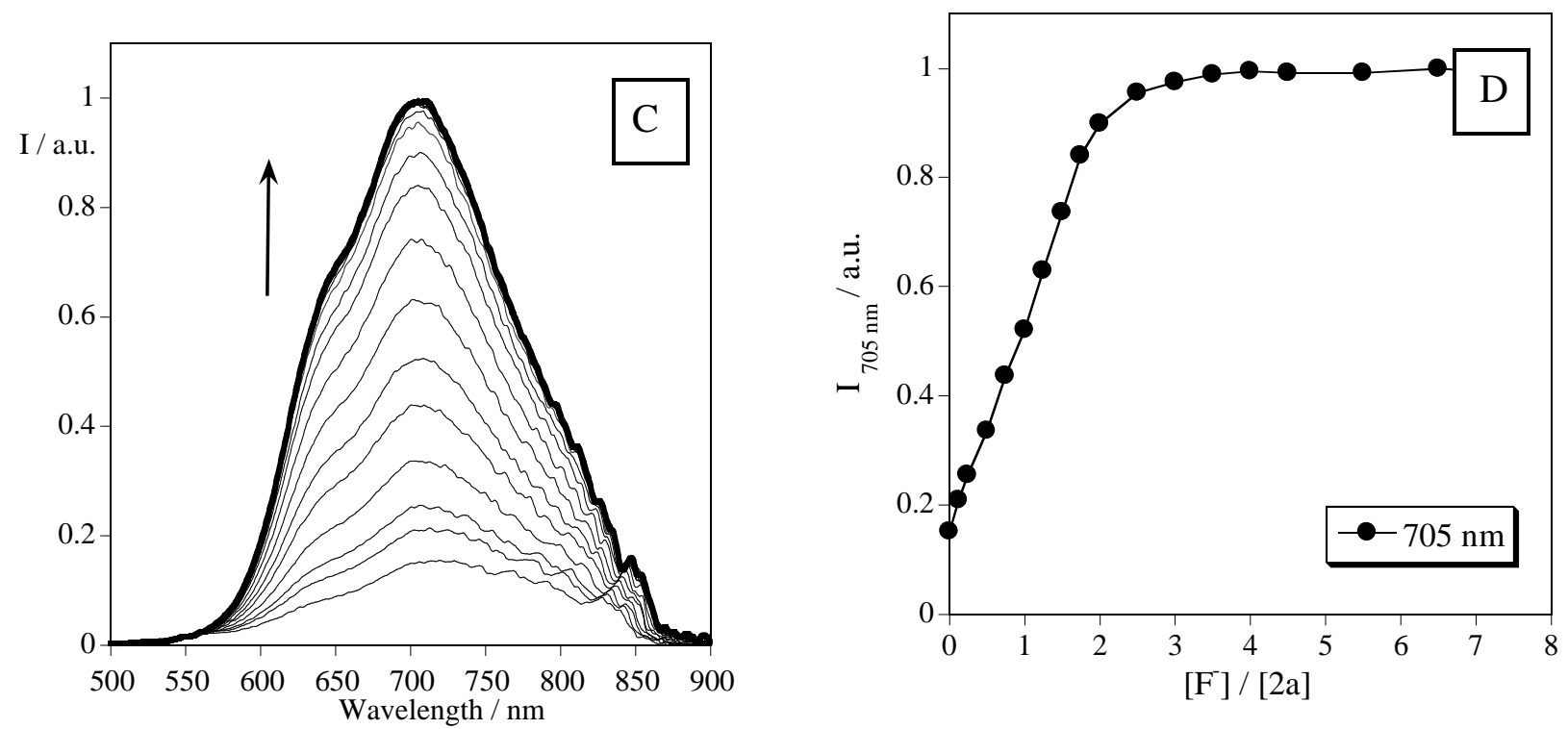

Figure S9. Fluorimetric titration of an $\mathrm{CH}_{3} \mathrm{CN}$ solution of $2 \mathbf{a}$ with a standard $\mathrm{CH}_{3} \mathrm{CN}$ solution of $\left[(\mathrm{Bu})_{4} \mathrm{~N}\right] \mathrm{F}(\mathrm{C})$ and $(\mathrm{D})$ Maximum of emission at $705 \mathrm{~nm}$ as a function of fluoride added; [2a] $=1.75 \times 10^{-5} \mathrm{M}, \lambda_{\mathrm{exc}}=450 \mathrm{~nm}, \mathrm{~T}=25^{\circ} \mathrm{C}$. 


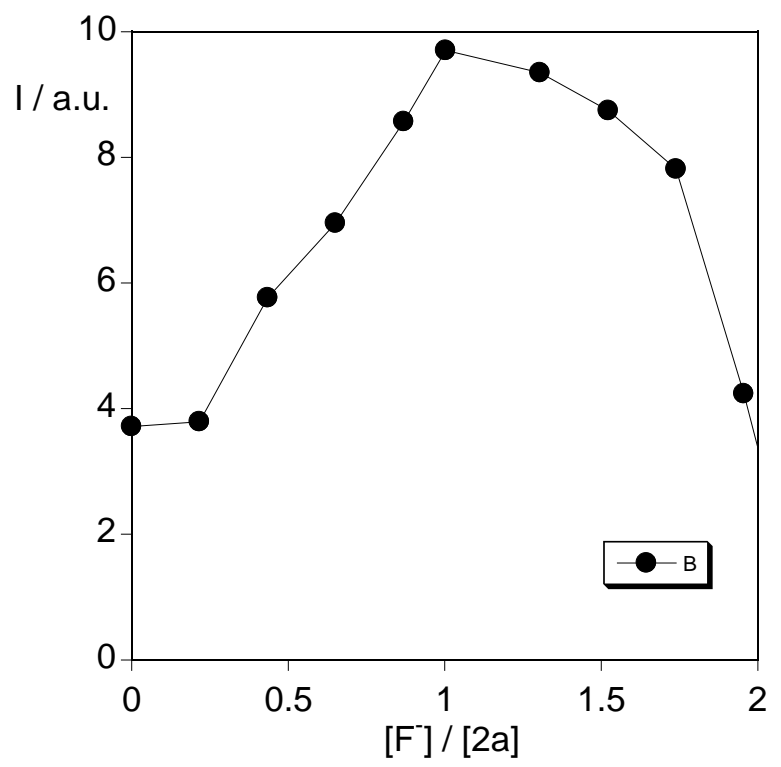

Figure S10. Stoichiometric study for the interaction between fluoride ion and compound 2a. The total concentration $\left[\mathrm{F}^{-}\right]+[\mathbf{2 a}]=2.0 \times 10^{-5} \mathrm{M}$.
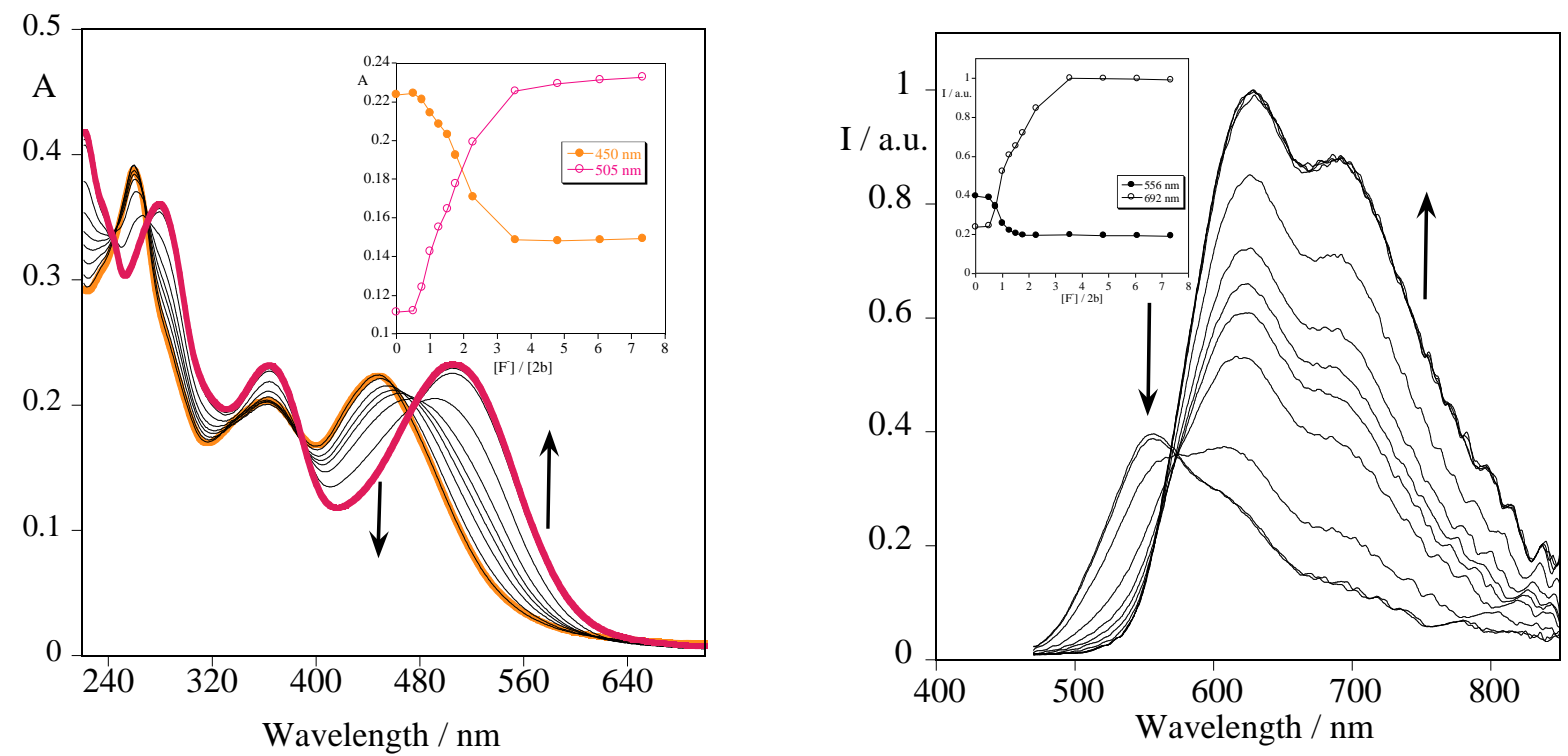

Figure S11. UV-vis and fluorescence emission spectra of $\mathbf{2} \mathbf{b}$ in $\mathrm{CH}_{3} \mathrm{CN}$ upon addition of increasing amount of $\left[(\mathrm{Bu})_{4} \mathrm{~N}\right] \mathrm{F} ;[2 \mathbf{b}]=1.60 \times 10^{-5} \mathrm{M}, \lambda_{\mathrm{exc}}=450 \mathrm{~nm}, \mathrm{~T}=25^{\circ} \mathrm{C}$. 

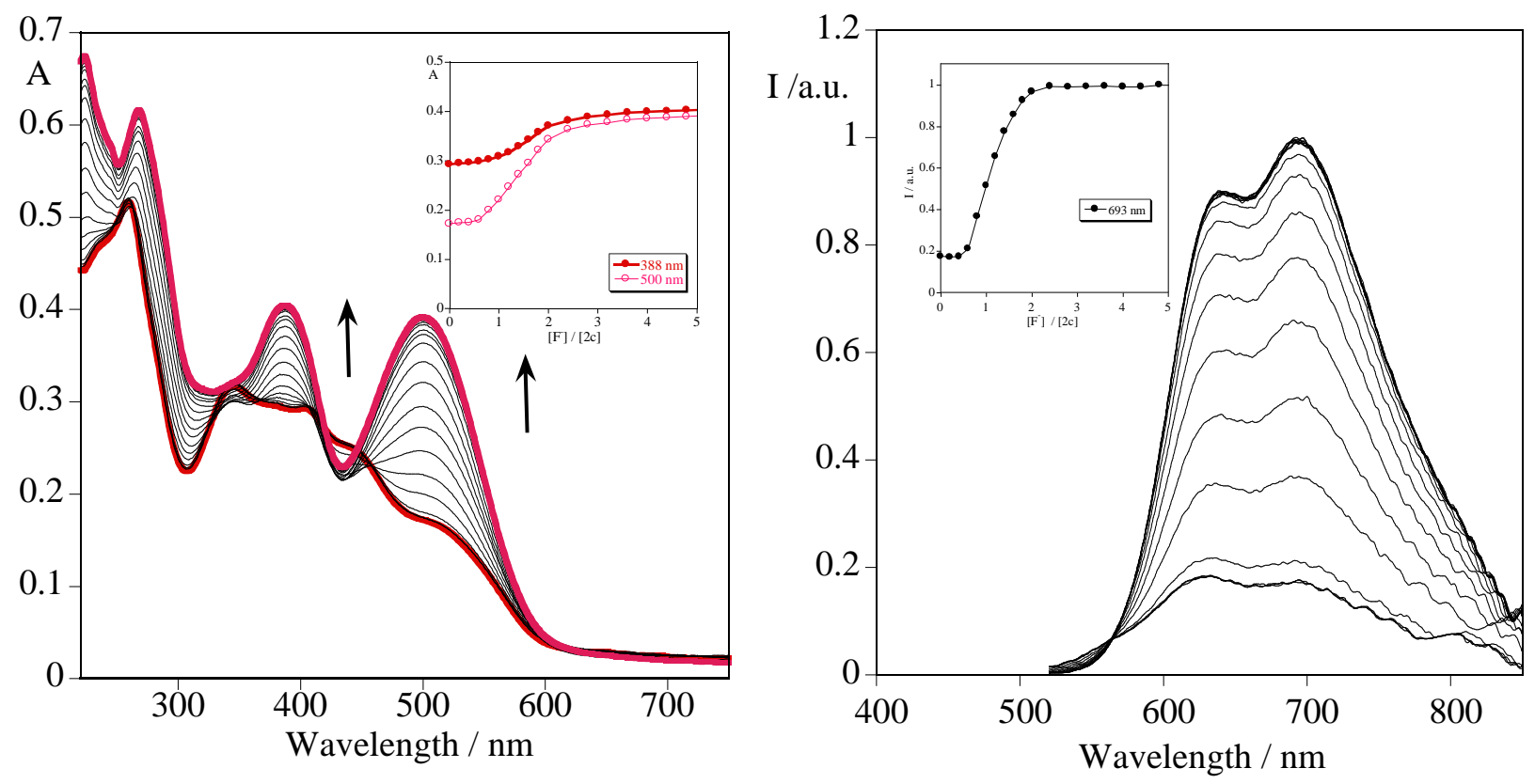

Figure S12. Uv-vis and fluorescence emission spectra of $2 \mathrm{c}$ in $\mathrm{CH}_{3} \mathrm{CN}$ upon addition of increasing amount of $\left[(\mathrm{Bu})_{4} \mathrm{~N}\right] \mathrm{F}$. $\left([2 \mathrm{c}]=2.00 \times 10^{-5} \mathrm{M}, \lambda_{\mathrm{exc}}=450 \mathrm{~nm}, \mathrm{~T}=25^{\circ} \mathrm{C}\right)$
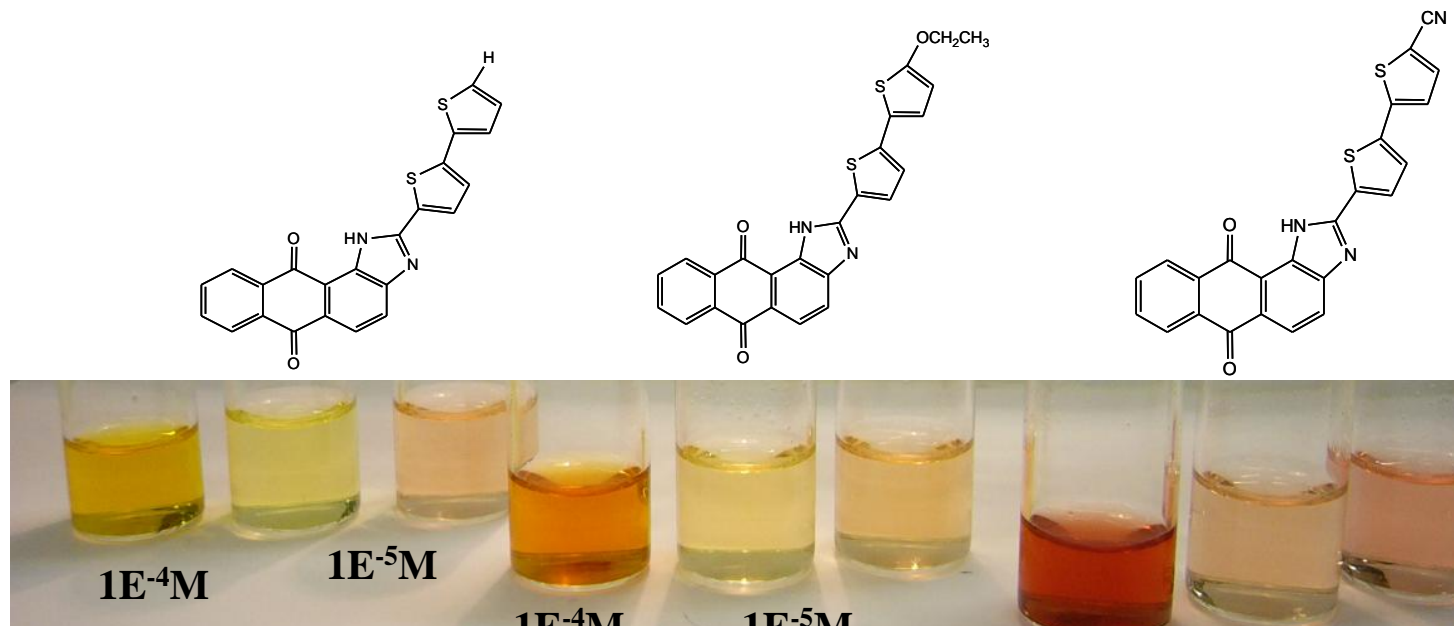

$\mathrm{CH}_{3} \mathrm{CN}$

$1 \mathrm{E}^{-4} \mathrm{M}$
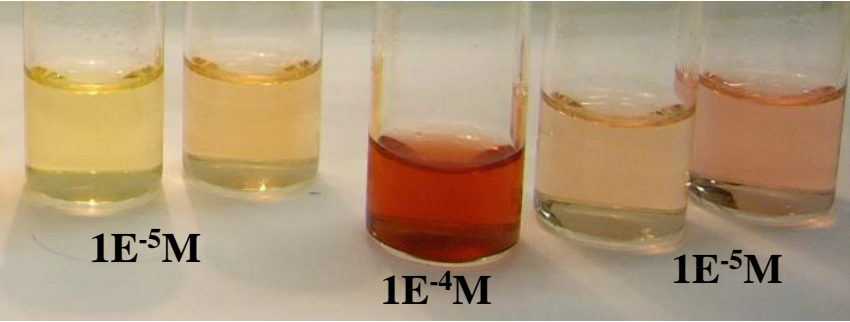

2a

2b

2c

Figure S13. Colorimetric effect in systems 2a-c after interaction with fluoride ion in acetonitrile. 


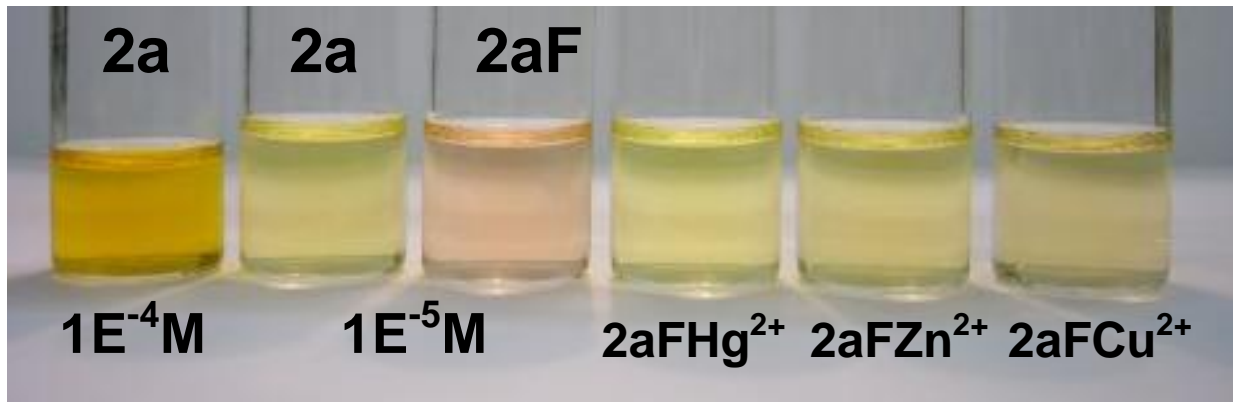

Figure S14. Colorimetric effect in compound 2a after interaction with fluoride ion, fluoride and mercury(II), fluoride and zinc(II) and fluoride and copper(II). 


\subsection{UV-vis and emission titration of 2a-c with metal ions, after fluoride ion addition.}
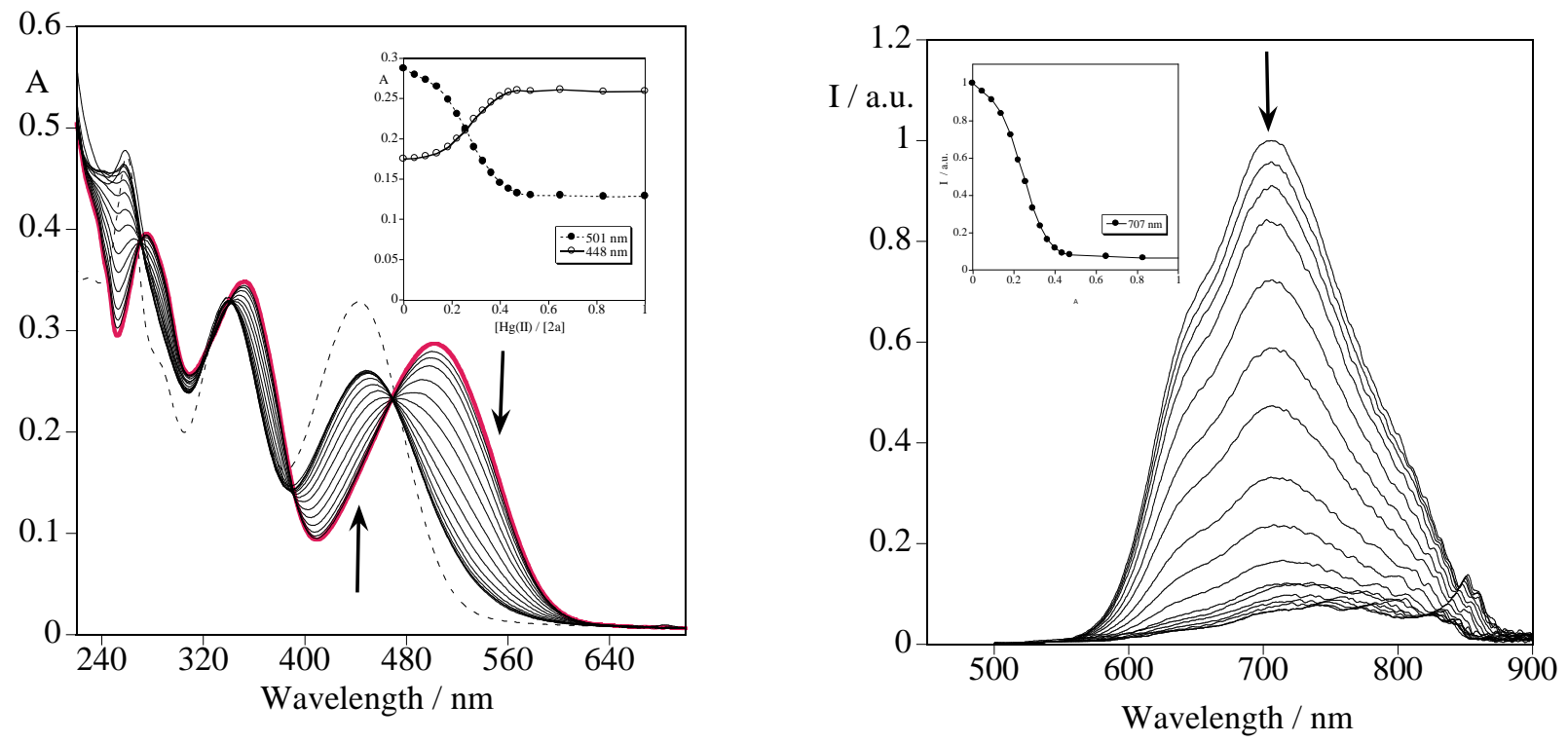

Figure S15. UV-vis and emission titration of $\mathbf{2 a}$ in $\mathrm{CH}_{3} \mathrm{CN}$ with increasing addition of $\mathrm{Hg}\left(\mathrm{CF}_{3} \mathrm{SO}_{3}\right)_{2}$ after addition of $\left[(\mathrm{Bu})_{4} \mathrm{~N}\right] \mathrm{F}$. $\left(\lambda_{\text {exc }}=470 \mathrm{~nm}\right)$. Dotted line: spectra of the free ligand.
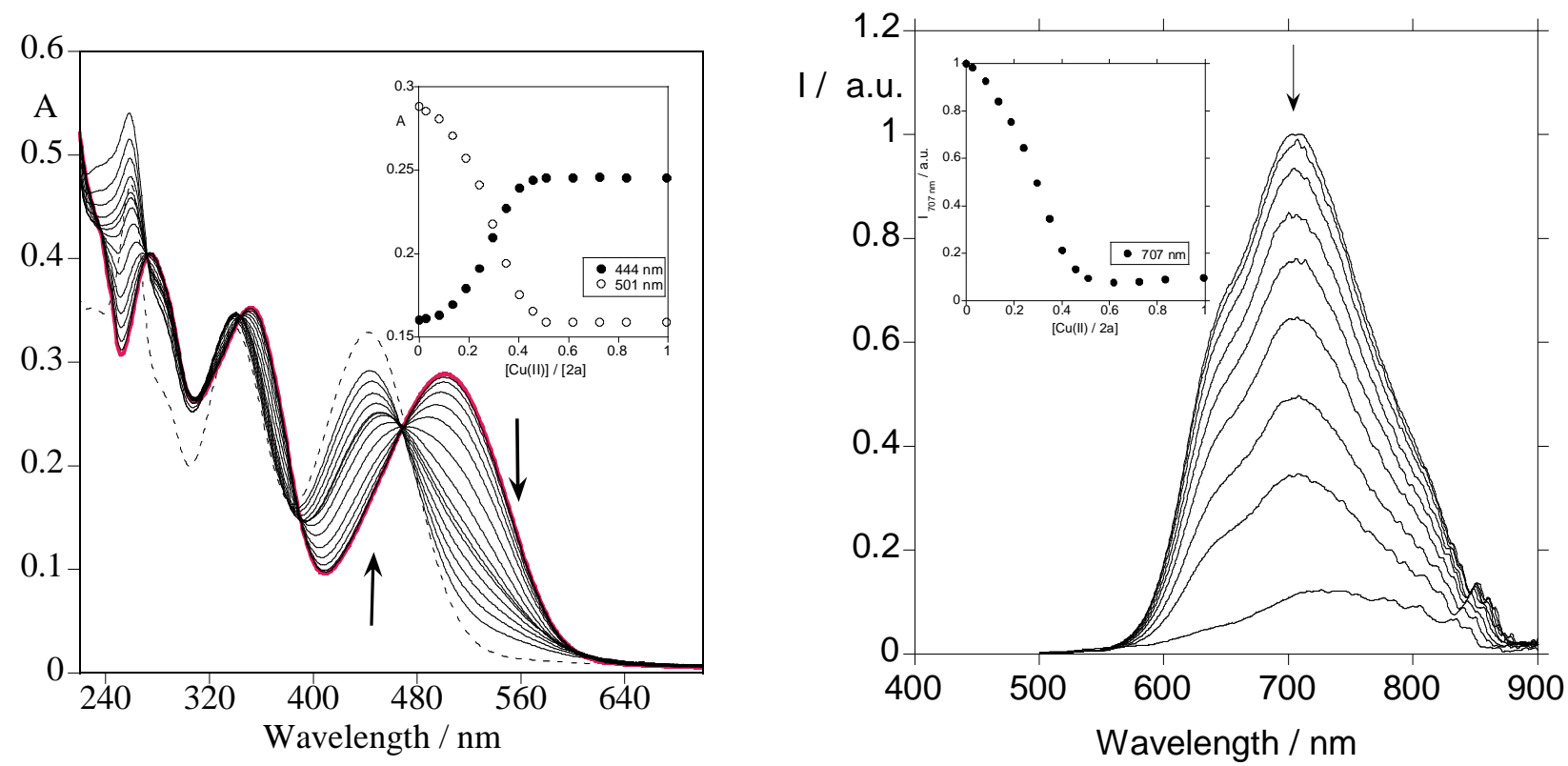

Figure S16. UV-vis and emission titration of $\mathbf{2 a}$ in $\mathrm{CH}_{3} \mathrm{CN}$ with increasing addition of $\mathrm{Cu}\left(\mathrm{CF}_{3} \mathrm{SO}_{3}\right)_{2}$ after addition of $\left[(\mathrm{Bu})_{4} \mathrm{~N}\right] \mathrm{F}$. $\left(\lambda_{\text {exc }}=470 \mathrm{~nm}\right)$. Dotted line: spectra of the free ligand. 

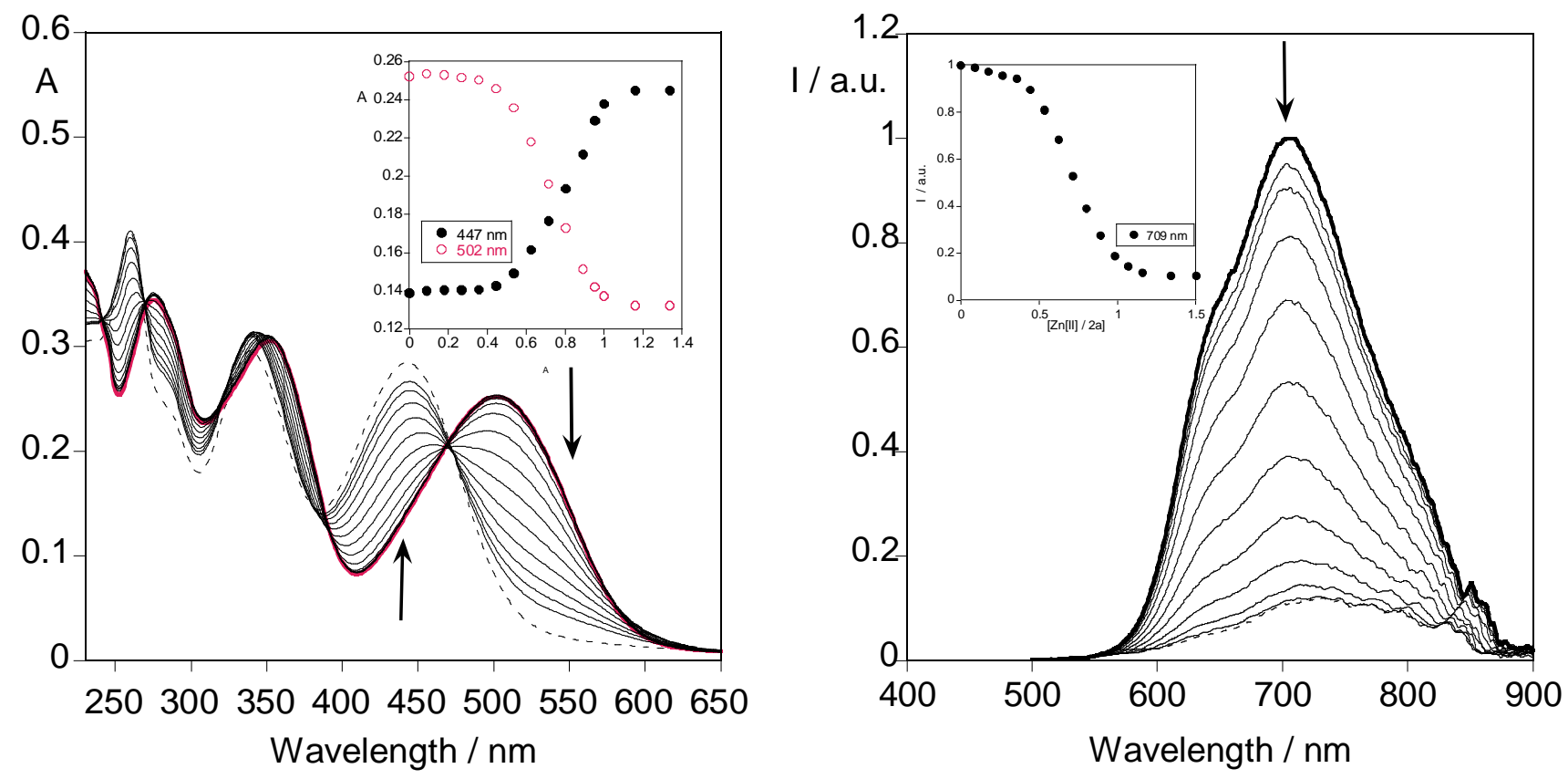

Figure S17. UV-vis and emission titration of $\mathbf{2 a}$ in $\mathrm{CH}_{3} \mathrm{CN}$ with increasing addition of $\mathrm{Zn}\left(\mathrm{CF}_{3} \mathrm{SO}_{3}\right)_{2}$ after addition of $\left[(\mathrm{Bu})_{4} \mathrm{~N}\right] \mathrm{F} .\left(\lambda_{\mathrm{exc}}=470 \mathrm{~nm}\right)$. Dotted line: spectra of the free ligand.
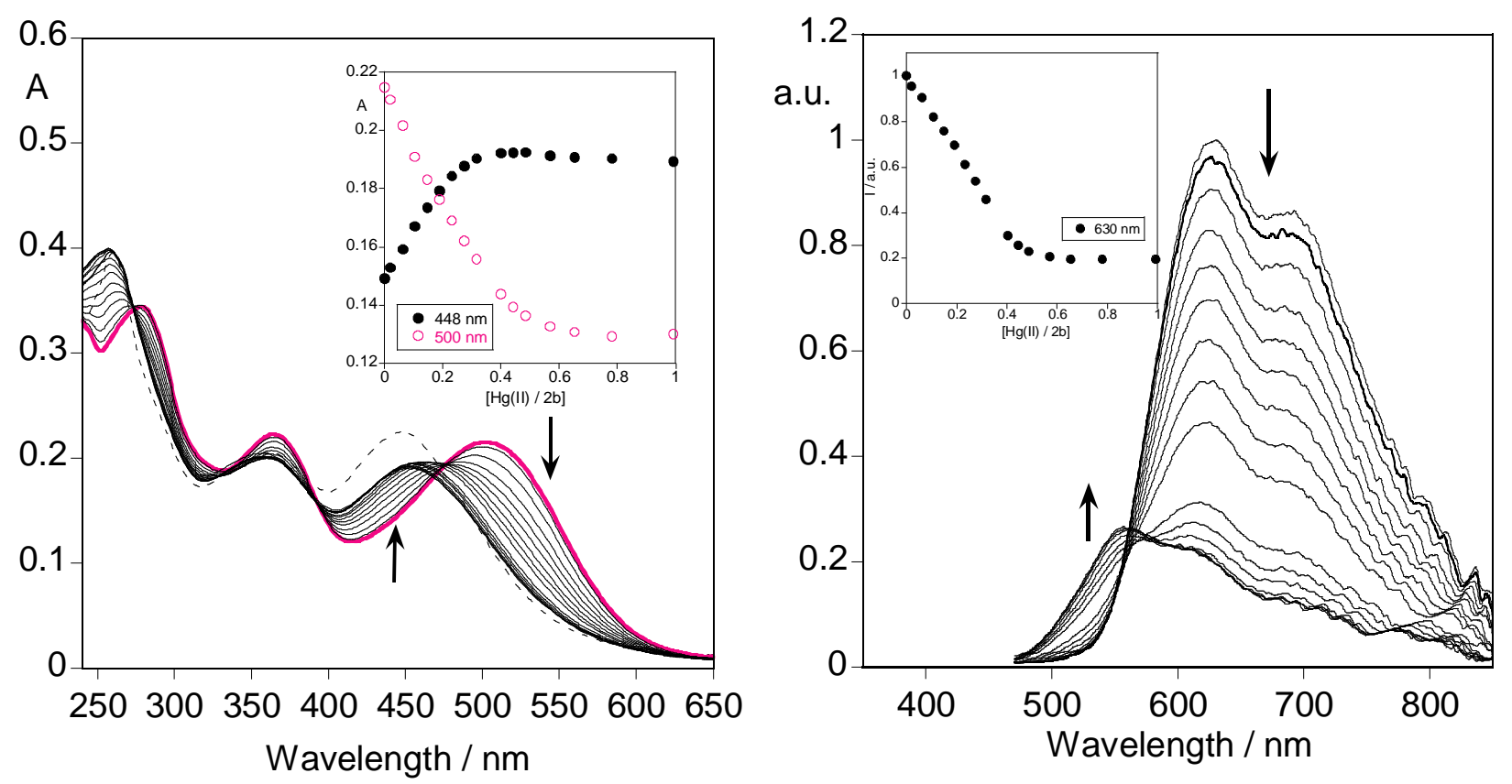

Figure S18. Representative metal ion UV-vis and emission titration of $\mathbf{2 b}$ in $\mathrm{CH}_{3} \mathrm{CN}$ with increasing addition of $\mathrm{Hg}\left(\mathrm{CF}_{3} \mathrm{SO}_{3}\right)_{2}$ after addition of $\left[(\mathrm{Bu})_{4} \mathrm{~N}\right] \mathrm{F} .\left(\lambda_{\text {exc }}=470 \mathrm{~nm}\right)$. The metal ion titration with $\mathrm{Zn}\left(\mathrm{CF}_{3} \mathrm{SO}_{3}\right)_{2}$ and $\mathrm{Cu}\left(\mathrm{CF}_{3} \mathrm{SO}_{3}\right)_{2}$ are similar. 

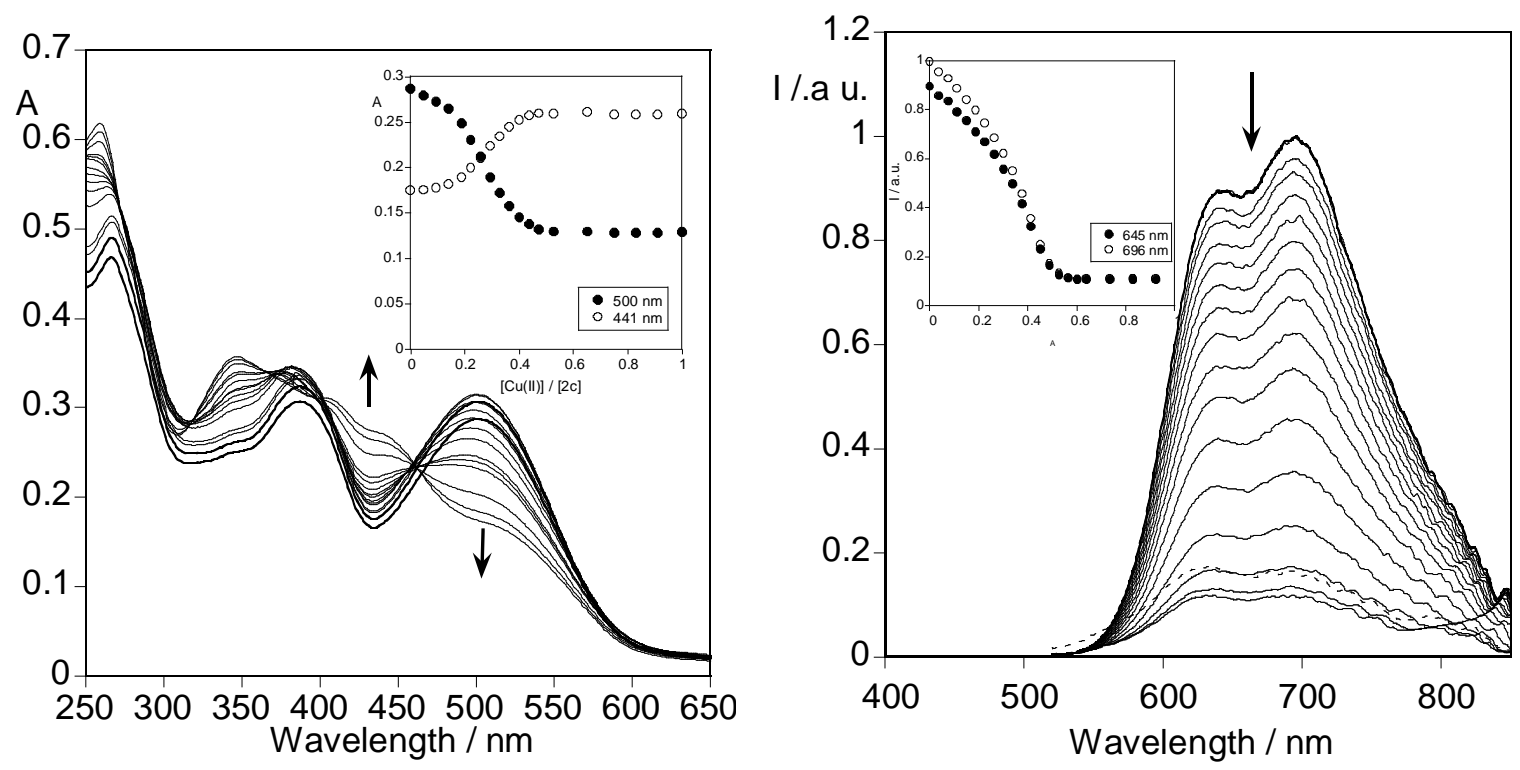

Figure S19. Representative metal ion UV-vis and emission titration of $\mathbf{2 c}$ in $\mathrm{CH}_{3} \mathrm{CN}$ with the increase addition of $\mathrm{Cu}\left(\mathrm{CF}_{3} \mathrm{SO}_{3}\right)_{2}$ after addition of $\left[(\mathrm{Bu})_{4} \mathrm{~N}\right] \mathrm{F}$. $\left(\lambda_{\text {exc }}=470 \mathrm{~nm}\right)$ The metal ion titration with $\mathrm{Zn}\left(\mathrm{CF}_{3} \mathrm{SO}_{3}\right)_{2}$ and $\mathrm{Hg}\left(\mathrm{CF}_{3} \mathrm{SO}_{3}\right)_{2}$ are similar.

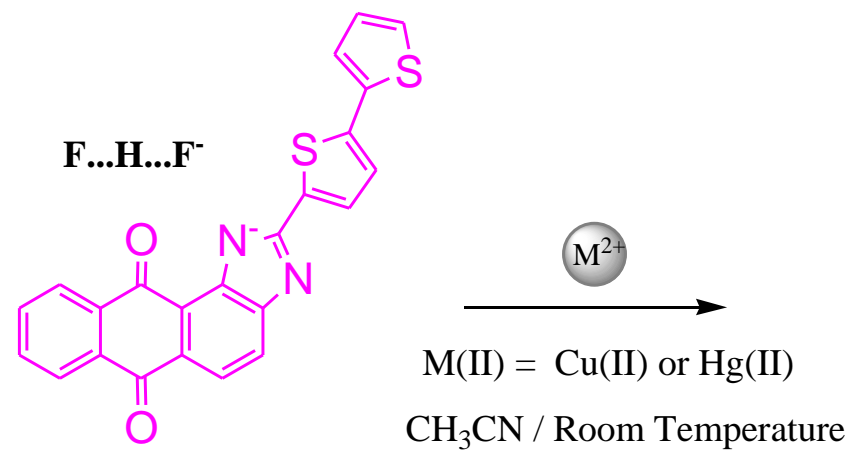

Emissive ligand

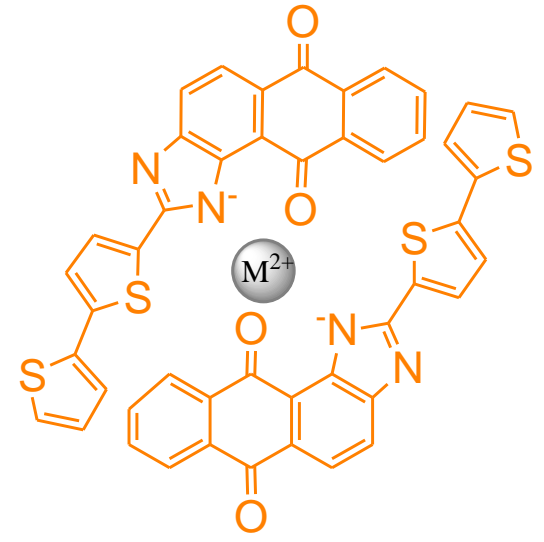

Non-emissive complexes

Figure S20. Schematic representation of the complexes of $\mathrm{Cu}(\mathrm{II})$ and $\mathrm{Hg}(\mathrm{II})$ formed with ligand 2a. Similar complexes can be proposed for $\mathbf{2 b}$ and $\mathbf{2 c}$. 


\section{References}

1. Raposo, M. M. M.; Kirsch, G. Tetrahedron 2003, 59(26), 4891.

2. a) Berlan, I. B. Handbook of Fluorescence Spectra of Aromatic Molecules, 2nd ed.; Academic Press: New York, 1971.; b) Melhuish, W. H. J. Phys Chem., 1961, 84, 229-235 